Article

\title{
Characterization of Chlorhexidine-Loaded Calcium-Hydroxide Microparticles as a Potential Dental Pulp-Capping Material
}

\author{
Balasankar M. Priyadarshini ${ }^{1}$, Subramanian T. Selvan ${ }^{2}$, Karthikeyan Narayanan ${ }^{3}$ \\ and Amr S. Fawzy 1,* \\ 1 Discipline of Oral Sciences, Faculty of Dentistry, National University of Singapore, \\ 11 Lower Kent Ridge Road, Singapore 119083, Singapore; a0106278@u.nus.edu \\ 2 Department of Chemistry, Myongji University, Natural Science Campus, 116 Myongji-ro, Cheoin-gu, \\ Yongin, Gyeonggi-do 449-728, Korea; selvant@mju.ac.kr \\ 3 Institute of Bioengineering and Nanotechnology, 31 Biopolis Way, The Nanos, \#04-01, Singapore 138669, \\ Singapore; karthisurya2002@gmail.com \\ * Correspondence: denasfmf@nus.edu.sg
}

Academic Editor: Frank Alexis

Received: 15 May 2017; Accepted: 19 June 2017; Published: 22 June 2017

\begin{abstract}
This study explores the delivery of novel calcium hydroxide $\left[\mathrm{Ca}(\mathrm{OH})_{2}\right]$ microparticles loaded with chlorhexidine (CHX) for potential dental therapeutic and preventive applications. Herein, we introduce a new approach for drug-delivery to deep dentin-surfaces in the form of drug-loaded microparticles. Unloaded $\mathrm{Ca}(\mathrm{OH})_{2}\left[\mathrm{Ca}(\mathrm{OH})_{2} /\right.$ Blank $]$ and $\mathrm{CHX}$-loaded $/ \mathrm{Ca}(\mathrm{OH})_{2}$ microparticles were fabricated by aqueous chemical-precipitation technique. The synthesized-microparticles were characterized in vitro for determination of surface-morphology, crystalline-features and thermal-properties examined by energy-dispersive $X$-ray scanning and transmission electron-microscopy (EDX-SEM/TEM), Fourier-transform infrared-spectroscopy (FTIR), X-ray diffraction (XRD), thermogravimetric analysis (TGA) and differential scanning-calorimetry (DSC). Time-related $\mathrm{pH}$ changes, initial antibacterial/biofilm-abilities and cytotoxicity of $\mathrm{CHX}$-loaded $/ \mathrm{Ca}(\mathrm{OH})_{2}$ microparticles were evaluated. Microparticles were delivered to dentin-surfaces with subsequent SEM examination of treated dentin-substrates. The in vitro and ex vivo $\mathrm{CHX}$-release profiles were characterized. $\mathrm{Ca}(\mathrm{OH})_{2}$ / Blank were hexagonal-shaped with highest $z$-average diameter whereas CHX-inclusion evidenced micro-metric spheres with distinguishable surface "rounded deposits" and a negative-shift in diameter. $\mathrm{CHX}: \mathrm{Ca}(\mathrm{OH})_{2} / 50 \mathrm{mg}$ exhibited maximum encapsulation-efficiency with good antibacterial and cytocompatible properties. SEM examination revealed an intact layer of microparticles on exposed dentin-surfaces with retention of spherical shape and smooth texture. Microparticles loaded on dentin-surfaces showed prolonged release of CHX indicating substantial retention on dentin-substrates. This study validated the inherent-applicability of this novel drug-delivery approach to dentin-surfaces using micro-metric $\mathrm{CHX}$-loaded $/ \mathrm{Ca}(\mathrm{OH})_{2}$ microparticles.
\end{abstract}

Keywords: chlorhexidine; dentin surfaces; dentinal tubules; microparticles; calcium hydroxide

\section{Introduction}

Restoration of tooth structure with retention of pulp vitality is an important essence of restorative dentistry [1]. Vital pulp therapy (VPT) provides the advantage of preserving the dental pulp tissue that has been compromised by caries, trauma or restorative procedures and stimulates the remaining pulp to regenerate reparative dentin [1,2]. Clinical studies have highlighted the success of materials 
such as calcium hydroxide $\left[\mathrm{Ca}(\mathrm{OH})_{2}\right]$, zinc oxide eugenol (ZOE) and mineral trioxide aggregate (MTA) in effective pulp-capping procedures [3,4]. Of these, calcium hydroxide was originally introduced to the field of endodontics as an intracanal pulp-capping/apexification agent owing to its high alkalinity and biocompatible nature; which however has extensive applications in modern clinical dentistry [5]. Most studies on the applications of calcium hydroxide have focused on some of its biological properties such as antibacterial efficacy, dentin-remineralization and stimulation of reparative bridge formation [6,7]. Traditionally, $\mathrm{Ca}(\mathrm{OH})_{2}$ dressings (such as the commercially available products; Dycal ${ }^{\circledR}$ DENTSPLY and Pulpdent ${ }^{\circledR}$ Paste) have been applied on the deepest layer of the affected dentin intentionally left remaining over the dental pulp tissue. In a large percentage of cases, this aided in the formation of a calcified reparative barrier that prevents possible pulp exposure thereby protecting the underlying pulp tissue from further injury [8,9]. Moreover, the alkaline $\mathrm{pH}$ of $\mathrm{Ca}(\mathrm{OH})_{2}$ has been implied in the stimulation of reparative dentin formation [10]. Although benefits of $\mathrm{Ca}(\mathrm{OH})_{2}$ have been regarded, concerns such as pulp inflammation upon $\mathrm{Ca}(\mathrm{OH})_{2}$ exposure and reduced antibacterial activity due to formation of a defective barrier were previously addressed [11,12].

Chlorhexidine ( $\mathrm{CHX})$, a commonly-used dental antiseptic, has displayed a valuable therapeutic role as a pulp-capping disinfectant and non-specific Matrix Metallo Proteinases (MMPs) inhibitor with proven efficacy against MMP-2, $-8,-9$ trapped in dentin [13,14]. Often times, researchers have combined $\mathrm{Ca}(\mathrm{OH})_{2}$ with Chlorhexidine, by physical modification of both their commercially available forms to obtain pastes/powder for enhanced antimicrobial action and to achieve some degree of synergism $[15,16]$. Studies revealed that this combination effectively eradicated microorganisms that were not eliminated by $\mathrm{Ca}(\mathrm{OH})_{2}$ alone [16,17]. However, no additional advantage was reported [18]. Moreover, only few studies have perceived this combination for use in drug-delivery and scrutinized their resultant properties in vitro [19]. In this work, we have introduced a new approach to assess the potential of biodegradable drug-loaded microparticle formulation that can be used as an effective pulp-capping material with promising remineralization, MMPs inhibition and antibacterial properties. Chlorhexidine-loaded $\mathrm{Ca}(\mathrm{OH})_{2}\left[\mathrm{CHX}\right.$-loaded $\left./ \mathrm{Ca}(\mathrm{OH})_{2}\right]$ microparticles were utilized for this purpose by virtue of the proven success of this combination [20]. Our proposed principle was to deliver the active-drug (CHX) to the exposed deepest dentin adjoining the pulpo-dentinal junction in the form of micron-sized particles for effective delivery, retention, and extended CHX-release over time. Upon dentin application, $\mathrm{Ca}(\mathrm{OH})_{2}$ microparticles eventually degrade slowly to release significant CHX-doses in a controlled manner at pre-determined time-periods. The general aim of this study was to explore the delivery of novel calcium hydroxide microparticles loaded with chlorhexidine for potential dental therapeutic and preventive applications. Accordingly, the following specific aims will be identified: to extensively characterize the synthesized $\mathrm{CHX}$-loaded $/ \mathrm{Ca}(\mathrm{OH})_{2}$ microparticles in vitro, in terms of particle-size, surface-charge and morphology, CHX-loading and entrapment, in vitro release profile, spectral analyses, $\mathrm{pH}$ measurement, cytotoxicity testing and antibacterial/biofilm activity. In this work, we have evaluated the in vitro properties of the synthesized microparticles in comparison to reference pulp capping materials: Dycal ${ }^{\circledR}$ (Dentsply) and commercial $\mathrm{Ca}(\mathrm{OH})_{2}$ microparticles.

\section{Materials and Methods}

\subsection{Reagents and Materials}

Calcium chloride dihydrate $\left(\mathrm{CaCl}_{2} \cdot 2 \mathrm{H}_{2} \mathrm{O}\right)(\mathrm{Mw} \sim 147.01 \mathrm{~g} / \mathrm{mol})$, sodium hydroxide $(\mathrm{NaOH})$, $2 \%$ chlorhexidine gluconate, phosphate buffered saline (PBS), triton X-100 $\left[\mathrm{C}_{14} \mathrm{H}_{22} \mathrm{O}\left(\mathrm{C}_{2} \mathrm{H}_{4} \mathrm{O}\right)_{10}\right]$ and commercial $\mathrm{Ca}(\mathrm{OH})_{2}$ powder were obtained from Sigma-Aldrich (St. Louis, MO, USA). Brain heart infusion (BHI) broth and agar were obtained from Thermo-Scientific (Oxoid Limited, Hampshire, UK). Micro-brush applicators were purchased from 3M ESPE (St. Paul, MN, USA). Dycal ${ }^{\circledR}$ was purchased from Dentsply (Caulk, Milford, DE, USA); the catalyst and base pastes of Dycal were mixed in the ratio of 1:1 according to manufacturer's instructions. Whatman PTFE Membrane Filters (pore size: $0.45 \mu \mathrm{m}$; 
$\mathrm{L} \times \mathrm{W}: 300 \mathrm{~mm} \times 640 \mathrm{~mm}$ ) were purchased from Sigma-Aldrich (St. Louis, MO, USA). All chemicals used in this study, were of analytical grade and used without further purification.

\subsection{Synthesis of Microparticles}

The particulars of the synthesis procedure of the CHX-loaded $/ \mathrm{Ca}(\mathrm{OH})_{2}$ and the unloaded $\left[\mathrm{Ca}(\mathrm{OH})_{2} /\right.$ Blank] microparticles are pictorially represented in Figure 1a. The $\mathrm{Ca}(\mathrm{OH})_{2} /$ Blank and the CHX-loaded $/ \mathrm{Ca}(\mathrm{OH})_{2}$ microparticles were prepared by a modified aqueous chemical-precipitation method [21]. Briefly, the aqueous solutions containing $0.3 \mathrm{~mol} / \mathrm{L}$ of $\mathrm{CaCl}_{2} \cdot 2 \mathrm{H}_{2} \mathrm{O}$ and $0.6 \mathrm{~mol} / \mathrm{L}$ of $\mathrm{NaOH}$ were prepared separately, with the supplementation of $0.15 \%$ of Triton $\mathrm{X}-100$ to these initial solutions. Different amounts of 25 and $50 \mathrm{mg}$ of chlorhexidine ( $\mathrm{CHX}$ ) was added to the formulated $\mathrm{CaCl}_{2} \cdot 2 \mathrm{H}_{2} \mathrm{O}$ solution and mixed well. The modified $\mathrm{CaCl}_{2}$ solution was added drop-wise into the aqueous $\mathrm{NaOH}$ at $\sim 50{ }^{\circ} \mathrm{C}$, forming $\mathrm{CHX}$-loaded $/ \mathrm{Ca}(\mathrm{OH})_{2}$ microparticles at formulations of $\mathrm{CHX}: \mathrm{Ca}(\mathrm{OH})_{2} / 25 \mathrm{mg}$ and $\mathrm{CHX}: \mathrm{Ca}(\mathrm{OH})_{2} / 50 \mathrm{mg}$ respectively. A white chalky precipitate was obtained after $1 \mathrm{~h}$. The precipitate was recovered by centrifugation, vacuum desiccated to minimize the extent of carbonation process [22] and stored at $4{ }^{\circ} \mathrm{C}$ for further investigation and characterization. The blank-microparticles were synthesized in the same aforesaid method, without the supplementation of $\mathrm{CHX}$.

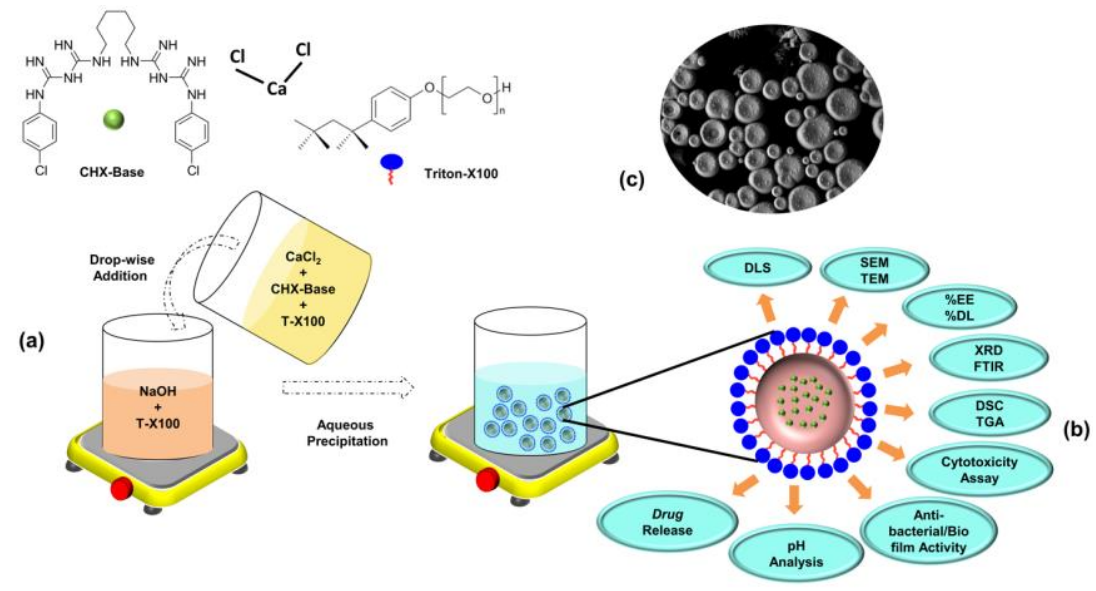

Figure 1. (a) Schematic illustration showing the synthesis and recovery of $\mathrm{CHX}$-loaded $/ \mathrm{Ca}(\mathrm{OH})_{2}$ microparticles by modified aqueous chemical-precipitation method. The aqueous solutions containing $0.3 \mathrm{~mol} / \mathrm{L}$ of $\mathrm{CaCl}_{2} \cdot 2 \mathrm{H}_{2} \mathrm{O}$ and $0.6 \mathrm{~mol} / \mathrm{L}$ of $\mathrm{NaOH}$ were prepared separately with the supplementation of $0.15 \%$ of Triton X-100 to both the above formulated initial solutions. Different amounts of 25 and $50 \mathrm{mg}$ of chlorhexidine (CHX) was added to the prepared $\mathrm{CaCl}_{2} \cdot 2 \mathrm{H}_{2} \mathrm{O}$ solution, blended well and added drop-wise into the aqueous $\mathrm{NaOH}$ solution at about $50{ }^{\circ} \mathrm{C}$. Two distinct phases consisting of a limpid supernatant and white chalky precipitate was observed at about $1 \mathrm{~h}$. The supernatant was discarded and the precipitate was purified by centrifugation, vacuum desiccated to minimize the extent of carbonation process followed by storage at $4{ }^{\circ} \mathrm{C}$ for further investigation and characterization. Unloaded $\mathrm{Ca}(\mathrm{OH})_{2}$ microparticles $\left(\mathrm{Ca}(\mathrm{OH})_{2}\right.$ / Blank) were synthesized following the same method as mentioned above without the supplementation of CHX. (b) Following synthesis and recovery, microparticles were characterized by dynamic light scattering (DLS), scanning and transmission electron-microscopy (SEM/TEM), quantitative-analysis, Fourier-transform infrared-spectroscopy (FTIR), X-ray diffraction studies (XRD), differential scanning-calorimetry (DSC), thermogravimetric analysis (TGA), in vitro cytotoxicity assay, antibacterial-activity, $\mathrm{pH}$ analysis and drug-release kinetics. (c) Representative SEM image of the synthesized spherical-shaped uniformly distributed $\mathrm{CHX}$-loaded $/ \mathrm{Ca}(\mathrm{OH})_{2}$ microparticles.

\subsection{Morphological Features}

The fabricated microparticles were characterized, in vitro, by various techniques indicated in Figure $1 \mathrm{~b}$,c. The $\mathrm{Ca}(\mathrm{OH})_{2}$ / Blank and the $\mathrm{CHX}$-loaded $/ \mathrm{Ca}(\mathrm{OH})_{2}$ microparticles (at formulations of 
$\mathrm{CHX}: \mathrm{Ca}(\mathrm{OH})_{2} / 25 \mathrm{mg}$ and $\mathrm{CHX}: \mathrm{Ca}(\mathrm{OH})_{2} / 50 \mathrm{mg}$ ) were characterized by dynamic light scattering (DLS) technique (Malvern Mastersizer Nano ZS, UK) for estimation of the $z$-average diameter, surface-charge and poly-dispersity index (PDI). Microparticles were diluted in distilled water [in the ratio of $1 / 50(w t / v)]$ and measurements were made at $37^{\circ} \mathrm{C}(\mathrm{n}=9)$. The particle shape, structure, morphology, surface texture, occurrence of the aggregation phenomena, the elemental composition and distribution on the surface of the synthesized $\mathrm{Ca}(\mathrm{OH})_{2} /$ Blank and the $\mathrm{CHX}$-loaded $/ \mathrm{Ca}(\mathrm{OH})_{2}$ microparticles were determined by SEM (Joel FESEM JSM-6700F, Japan) equipped with energy-dispersive X-ray spectroscopy (EDX-SEM; an Oxford/INCA EDS) $(n=5)$. Prior to examination, dried particles were spread on double-coated carbon adhesive tapes fixed on metal stubs and gold sputter-coated under an argon atmosphere (BAL-TEC, SCD 005 Sputter Coater, Scotia, NY, USA) for SEM imaging at an accelerating voltage of $10 \mathrm{kV}$. TEM examination of the $\mathrm{Ca}(\mathrm{OH})_{2} /$ Blank and the $\mathrm{CHX}$-loaded $/ \mathrm{Ca}(\mathrm{OH})_{2}$ microparticles was performed using the Joel-JSM-1010 (Japan). A drop of microparticles diluted in distilled water [in the ratio of 1:50 (wt/v)] were placed on carbon-coated copper grids and dried overnight. The dried samples were then examined using TEM.

\subsection{Encapsulation-Efficiency and Drug-Loading}

The percentage (\%) drug encapsulation-efficiency (EE) of the $\mathrm{CHX}$-loaded/Ca(OH $)_{2}$ microparticles (at formulations of $\mathrm{CHX}: \mathrm{Ca}(\mathrm{OH})_{2} / 25 \mathrm{mg}$ and $\mathrm{CHX}: \mathrm{Ca}(\mathrm{OH})_{2} / 50 \mathrm{mg}$ ) was determined by indirect-assay method. Microparticles were washed with distilled water, centrifuged and the supernatant was collected. Based on the standard curve plotted earlier, the amount of non-encapsulated (free) CHX in the supernatant was measured spectrophotometrically at $289 \mathrm{~nm}$ (UV-1700 Pharma Spec UV-VIS Spectrophotometer, Shimadzu, Japan) $(n=7)$. From the above estimated value, the amount of encapsulated CHX was determined. The percentage (\%) of drug encapsulation-efficiency (EE) and drug-loading (DL) were calculated using Equations (1) and (2).

$$
\begin{gathered}
\text { Encapsulation Efficiency }(\%)=\frac{\text { Mass of drug in microparticles } \times 100}{\text { Mass of drug added }} \\
\text { Drug loading }(\%)=\frac{\text { Mass of drug in microparticles } \times 100}{\text { Mass of particles recovered }}
\end{gathered}
$$

\subsection{Spectral and Thermal Analyses}

The IR spectra of the $\mathrm{Ca}(\mathrm{OH})_{2} /$ Blank and the $\mathrm{CHX}$-loaded $/ \mathrm{Ca}(\mathrm{OH})_{2}$ microparticles (at formulations of $\mathrm{CHX}: \mathrm{Ca}(\mathrm{OH})_{2} / 25 \mathrm{mg}$ and $\mathrm{CHX}: \mathrm{Ca}(\mathrm{OH})_{2} / 50 \mathrm{mg}$ ) were recorded using Perkin Elmer Spectrum RX-I (Waltham, MA) to detect the structural-features and confirm inclusion of $\mathrm{CHX}$ in the $\mathrm{CHX}$-loaded $/ \mathrm{Ca}(\mathrm{OH})_{2}$ microparticles. Powdered microparticles samples were mixed with $\mathrm{KBr}$ and pressed to pellets for measurements. Samples were run in duplicates and the spectra were obtained at frequency range of 4000 to $400 \mathrm{~cm}^{-1}$ at $4 \mathrm{~cm}^{-1}$ resolution. The X-ray powder diffraction (XRD) measurements were performed to determine the crystalline phases of the synthesized $\mathrm{Ca}(\mathrm{OH})_{2} /$ Blank and the $\mathrm{CHX}$-loaded $/ \mathrm{Ca}(\mathrm{OH})_{2}$ microparticles (at the formulations of $\mathrm{CHX}: \mathrm{Ca}(\mathrm{OH})_{2} / 25 \mathrm{mg}$ and $\left.\mathrm{CHX}: \mathrm{Ca}(\mathrm{OH})_{2} / 50 \mathrm{mg}\right)$ and confirm the presence of $\mathrm{CHX}$ in all the $\mathrm{CHX}: \mathrm{Ca}(\mathrm{OH})_{2}$ formulations. The data were collected for the powdered samples under laboratory conditions $\left(\mathrm{T}=20^{\circ} \mathrm{C}\right.$, relative humidity $\left.\mathrm{RH}=40 \%\right)$, using a Rigaku Miniflex X-ray diffractometer (Tokyo, Japan) using $\mathrm{Cu}-\mathrm{K} \alpha$ radiation $(\mathrm{k} \alpha 1=1.542 \AA)$. Data were collected over the $2 \theta$ range with a step size of $0.02^{\circ}$. The thermal stability of the $\mathrm{Ca}(\mathrm{OH})_{2} /$ Blank and the $\mathrm{CHX}$-loaded $/ \mathrm{Ca}(\mathrm{OH})_{2}$ microparticles (at formulations of $\mathrm{CHX}: \mathrm{Ca}(\mathrm{OH})_{2} / 25 \mathrm{mg}$ and $\mathrm{CHX}: \mathrm{Ca}(\mathrm{OH})_{2} / 50 \mathrm{mg}$ ) was verified by thermogravimetric analysis (TGA), using a TA Instrument Discovery TGA Thermogravimetric analyzer (New Castle, DE, USA). Approximately $10 \mathrm{mg}$ of the samples were placed in alumina crucibles and heated from room temperature to $800^{\circ} \mathrm{C}$ at a heating rate of $10^{\circ} \mathrm{C} \mathrm{min}-1$ under nitrogen atmosphere. Differential scanning calorimetry (DSC) thermograms of the $\mathrm{Ca}(\mathrm{OH})_{2} /$ Blank and the CHX-loaded $/ \mathrm{Ca}(\mathrm{OH})_{2}$ microparticles were obtained using a Mettler Toledo (DSC-1 system, Greifensee, 
Switzerland) for determining the physical state of the drug present in the microparticles formulations. About $2 \mathrm{mg}$ of the powdered samples placed in an aluminium pan were heated from room temperature to $400{ }^{\circ} \mathrm{C}$ under nitrogen atmosphere at a heating rate of $10^{\circ} \mathrm{C} \mathrm{min}^{-1}$.

\subsection{Evaluation of $p H$}

For determining the $\mathrm{pH}$, about $15 \mathrm{mg}$ of the microparticles and commercial $\mathrm{Ca}(\mathrm{OH})_{2}$ powder was suspended in $10 \mathrm{~mL}$ of distilled water and maintained at $37^{\circ} \mathrm{C}$. A standard Dycal disc was prepared according to the manufacturer's instructions, allowed to set and ground to fine powder using mortar and pestle. Further, Dycal samples were maintained under same conditions as that of the microparticles. The $\mathrm{pH}$ values were recorded using Thermo Scientific ${ }^{\mathrm{TM}}$ Orion $^{\mathrm{TM}}$ Star A211 $\mathrm{pH}$ Benchtop Meter (CO, Fort Collins, USA) for $0 \mathrm{~h}, 24 \mathrm{~h}, 7$ days and 15 days $(\mathrm{n}=13)$.

\subsection{Cytotoxicity Assay}

The in vitro cytotoxicity assay of the $\mathrm{Ca}(\mathrm{OH})_{2} /$ Blank and the $\mathrm{CHX}$-loaded $/ \mathrm{Ca}(\mathrm{OH})_{2}$ microparticles (at formulations of $\mathrm{CHX}: \mathrm{Ca}(\mathrm{OH})_{2} / 25 \mathrm{mg}$ and $\mathrm{CHX}: \mathrm{Ca}(\mathrm{OH})_{2} / 50 \mathrm{mg}$ ) was assessed by Vybrant MTT Cell Proliferation Assay Kit purchased from Thermo Fisher Scientific (Waltham, MA, USA). Human mesenchymal stem cells (hMSCs) (Cat \# PT-2501) were seeded in 96-well plates at $1 \times 10^{4}$ cells per well. Hundred microliters of suspended cells were added in Mesenchymal Stem Cell Growth Medium (MSCGM ${ }^{\mathrm{TM}}$ )/well (Lonza, Basel, Switzerland). After $24 \mathrm{~h}$ of plating, the cells were exposed to different concentrations $(20,60$ and $100 \mu \mathrm{g} / \mathrm{mL})$ of Dycal, pure $\mathrm{CHX}$, commercial $\mathrm{Ca}(\mathrm{OH})_{2}$ powder, $\mathrm{Ca}(\mathrm{OH})_{2} /$ Blank and CHX-loaded $/ \mathrm{Ca}(\mathrm{OH})_{2}$ microparticles (at formulations of $\mathrm{CHX}: \mathrm{Ca}(\mathrm{OH})_{2} / 25 \mathrm{mg}$ and $\left.\mathrm{CHX}: \mathrm{Ca}(\mathrm{OH})_{2} / 50 \mathrm{mg}\right)$. Dycal was prepared according to manufacturer's instructions, allowed to set and powdered (as mentioned previously). Dried powders of pure CHX, Dycal and microparticles were suspended in the culture medium (i.e. at concentration of $20 \mu \mathrm{g} / \mathrm{mL}, 20 \mu \mathrm{g}$ of nanoparticles were suspended in $1 \mathrm{~mL}$ of the culture medium). About $30 \mu \mathrm{L}$ of this suspension was directly added to the cultured cells. The cells were cultured for $24 \mathrm{~h}$ with the microparticles. Untreated-control cultures (cells and culture medium only) were also maintained in the same conditions. The cells were washed with PBS and subjected to MTT assay. Briefly, the cells were treated with $12 \mathrm{mM}$ of 3-(4,5-dimethylthiazol-2-yl)-2,5-diphenyltetrazolium bromide (MTT) stock solution in each well. After a $4 \mathrm{~h}$ incubation at $37^{\circ} \mathrm{C}, 100 \mu \mathrm{L}$ of SDS- $\mathrm{HCl}$ solution was added to each well and mixed thoroughly with the pipette. The microplate was incubated at $37^{\circ} \mathrm{C}$ in a humidified chamber for $3 \mathrm{~h}$. Each sample was mixed again using a pipette and the absorbance was read at $\lambda=570 \mathrm{~nm}$ in a microplate reader. The experiments were performed in triplicates $(n=7)$ and the percentage $(\%)$ cell viability was determined from the absorbance by taking the values of untreated group as $100 \%$.

\subsection{Agar-Diffusion Bacterial Inhibition Zone Test}

Streptococcus mutans ATCC UA159 and Enterococcus faecalis ATCC 29212 were the strains used in this study. Bacteria from frozen stock was recovered in $5 \mathrm{~mL}$ of brain-heart infusion (BHI) broth and cultured aerobically at $37^{\circ} \mathrm{C}$. From the overnight culture, an inoculum of 0.5 at OD600 (equivalent to $10^{8}$ bacteria $/ \mathrm{mL}$ ) was prepared in fresh BHI. About $100 \mu \mathrm{L}$ of each bacterial suspension was freshly seeded on BHI agar plate, swabbed and dried for $20 \mathrm{~min}$. In this method, the agar disk and well-diffusion procedures have been combined. Holes were cut in the agar plates and $30 \mu \mathrm{L}$ of $\mathrm{Ca}(\mathrm{OH})_{2} /$ Blank, CHX: $\mathrm{Ca}(\mathrm{OH})_{2}$ microparticles (at formulations of $\mathrm{CHX}: \mathrm{Ca}(\mathrm{OH})_{2} / 25 \mathrm{mg}$ and $\mathrm{CHX}: \mathrm{Ca}(\mathrm{OH})_{2} / 50 \mathrm{mg}$ ) and commercial $\mathrm{Ca}(\mathrm{OH})_{2}$ powder were placed in the holes. About $20 \mu \mathrm{L}$ of the corresponding positive-control $\mathrm{CHX}$ concentrations (dissolved in acetone) were deposited on the filter paper-disks, air-dried and evenly spaced on the prepared bacterial agar petri-dishes. Dycal was placed inside the well immediately after mixing both the catalyst and base pastes, in order for the paste to set inside the well. All plates were incubated at $37^{\circ} \mathrm{C}$ for $48 \mathrm{~h}(\mathrm{n}=13)$. The diameters of the inhibition-zones were measured in centimeters $(\mathrm{cm})$ with a slide gauge. 


\subsection{Preparation of Dentin-Specimens for Microparticles Application}

Non-carious and non-restored human molars (primarily extracted for clinical reasons) from patients of age range 21-35 years were chosen as ex vivo models for investigating the application of the $\mathrm{CHX}$-loaded $/ \mathrm{Ca}(\mathrm{OH})_{2}$ to dentin-substrates. Generic ethical approval and consent has been acquired for research to be conducted on the collected teeth from the Institutional Review Board of the National University of Singapore. The collected teeth were stored in $0.5 \%$ Chloramine-T solution for 2 weeks after which they were stored in distilled water at $4{ }^{\circ} \mathrm{C}$ and used within two months from the extraction time. A low-speed diamond saw (Buehler, Lake Bluff, IL, USA) was used to obtain flat, transversely cut dentin-specimens under water-coolant as shown in Figure 2a,b. The specimens were then wet-ground under water-coolant with 600 through 4000 grit-size silicon-carbide abrasive papers (Carbimet; Buehler Ltd., Lake Bluff, IL, USA) using a micro-grinder/polisher machine (Phoenix Beta Polisher/Grinder, Phoenix, AZ, USA). The dentin-specimens were ultrasonically cleaned for $10 \mathrm{~min}$ and rinsed with distilled water. Remnants of the pulp-tissues were removed by gentle excavation followed by normal saline irrigation. 


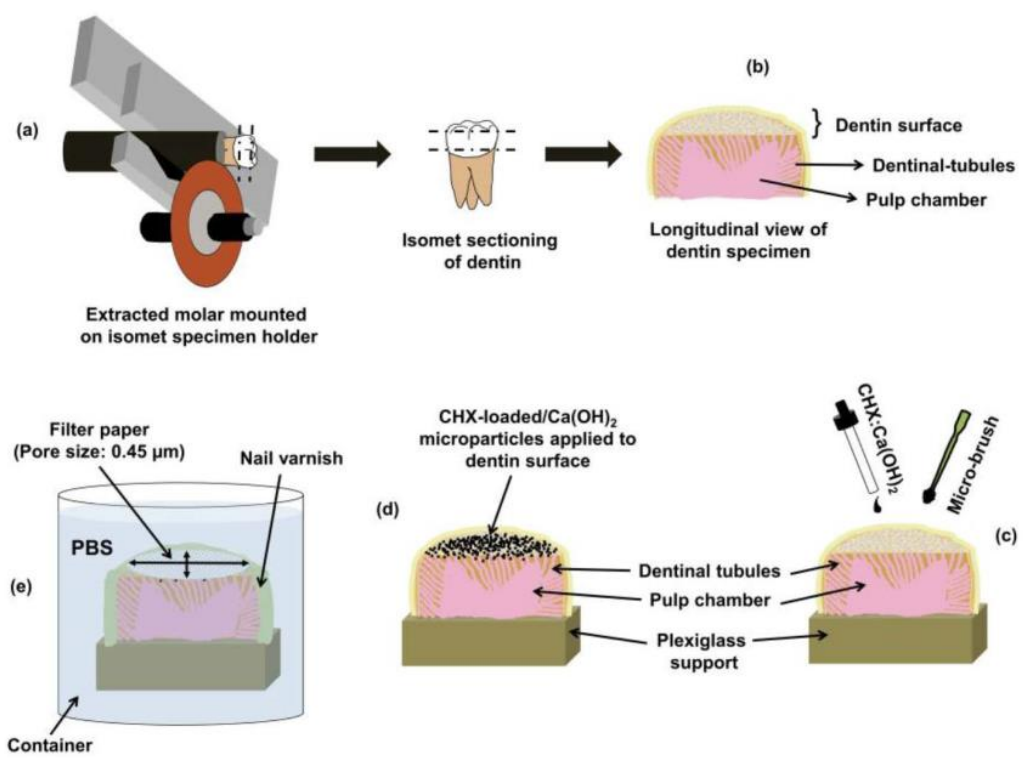

Figure 2. (a) Schematic sketch demonstrating the isomet sectioning procedure of extracted human molars for obtaining dentin-specimens used for microparticles delivery, the ex vivo drug-release experiments, and the confocal imaging for Live/Dead assay. The occlusal enamel surface was removed using low-speed diamond saw exposing the superficial-dentin approximately $3 \mathrm{~mm}$ beneath the DEJ (deep dentin). The dentin specimens were prepared by cutting parallel to the exposed dentin surface, about $0.5 \mathrm{~mm}$ above the CEJ, under running water. (b) After sectioning, the dentin specimens were wet-ground using 600 through 4000 grit-size silicon-carbide papers. The prepared dentin-surfaces were cleaned ultrasonically for $10 \mathrm{~min}$ and rinsed with distilled water. (c) Representative sketch showing the procedure of treatment of the prepared dentin-surface with $30 \mu \mathrm{L}$ of microparticles suspended in distilled water (at the working ratio of $1 / 1(w t / v)$ ), applied drop-by-drop for $60 \mathrm{~s}$ followed by gentle spreading on the surface by micro-brush for $5 \mathrm{~s}$. Following application, the dentin-surface was gently air-blown for $3 \mathrm{~s}$ and the excess water was blot-dried by absorbent paper. (d) The $\mathrm{CHX}$-loaded $/ \mathrm{Ca}(\mathrm{OH})_{2}$ microparticles attached to the exposed dentin-surface following treatment. (e) For characterization of CHX-release profiles from microparticles delivered to the dentin-substrates, oval-shaped filter-paper strips (Whatman PTFE membrane filters; average pore size: $0.45 \mu \mathrm{m})(8 \mathrm{~mm} \times 5 \mathrm{~mm})$ were placed on the exposed surfaces of the microparticles-loaded dentin-specimens, just enough to cover the surface. The other exposed areas that are not covered by the filter paper were sealed with a water-proof nail varnish to standardize the area for CHX-release. The entire set-up was placed inside a container filled with $10 \mathrm{~mL}$ PBS for determining the ex vivo release of $\mathrm{CHX}$ into the surrounding release media over pre-determined time-intervals. The amount of CHX liberated from dentin into the surrounding PBS release medium was analyzed spectrophotometrically. N.B: The longitudinal section of the prepared dentin specimen displayed in the schematic sketch is only used for demonstration purpose. It is important to note that no longitudinal sectioning was performed and the dentin specimens were used as an intact specimen throughout the ex vivo experiments. * DEJ: Dentino-enamel junction; CEJ: Cemento-enamel junction.

\subsection{Microparticles Application to Surface-Prepared Dentin-Substrates}

The prepared dentin-specimens were randomly grouped to be treated with: (i) $\mathrm{Ca}(\mathrm{OH})_{2} /$ Blank (control), (ii) $\mathrm{CHX}: \mathrm{Ca}(\mathrm{OH})_{2} / 25 \mathrm{mg}$ microparticles and (iii) $\mathrm{CHX}: \mathrm{Ca}(\mathrm{OH})_{2} / 50 \mathrm{mg}$ microparticles. Water was used as the microparticles' carrier at the microparticles/carrier working ratio of $1 / 1(w t / v)$. An amount of $30 \mu \mathrm{L}$ of microparticles/carrier suspension was applied drop-by-drop to the prepared dentin-specimens for $60 \mathrm{~s}$ followed by gentle spreading on the surface by micro-brush rubbing for $5 \mathrm{~s}$ as shown in Figure 2c,d. After microparticles application, the dentin-substrates were gently air-blown for $3 \mathrm{~s}$ and the excess water was blot-dried by absorbent paper. The dentin-specimens treated with the microparticles were prepared for SEM examination. 


\subsection{Biofilm Formation and Live/Dead Cell Assay}

For biofilm formation, the inoculation of Streptococcus mutans (ATCC UA159) and Enterococcus faecalis (ATCC 29212) suspensions adjusted to OD 0.5 at $600 \mathrm{~nm}$ (equivalent to $10^{8}$ bacteria/mL) were prepared as mentioned previously. Dentin-specimens treated with the microparticles were used as substrates for biofilm attachment and growth. Dentin-specimens were placed in 24-well plate (one-specimen per well) inoculated with $1 \mathrm{~mL}$ of bacterial suspension cells at $37^{\circ} \mathrm{C}$ in $5 \% \mathrm{CO}_{2}$ and left undisturbed for 3 days $(n=5)$. Every $24 \mathrm{~h}$ the samples were replenished with $\mathrm{BHI}$ medium to remove non-adherent cells.

The S. mutans and E. faecalis biofilms attached on the microparticle-treated dentin specimens were stained with Film Tracer ${ }^{\mathrm{TM}}$ LIVE/DEAD Biofilm Viability kit (Life Technologies-Invitrogen, Grand Island, NY, USA) using SYTO-9 dye and propidium iodide (PI) (ratio of 1:1), according to the manufacturer's instructions. SYTO-9 stains metabolically active cells that emits a green fluorescence (excitation/emission wavelength of 480/500 nm) while PI stains dead cells giving a red fluorescence (excitation/emission wavelength of $490 / 635 \mathrm{~nm}$ ) [23]. Stained dentin-specimens were rinsed with $1 \mathrm{~mL}$ of sterile distilled water. Samples were later imaged using a $60 \times$ water immersion lens fitted to a confocal laser scanning microscope (Olympus Fluoview 1000; Olympus, Tokyo, Japan). The fluorescence signal intensities of biofilm were analyzed with IMARIS 6.3 software (Biplanes Scientific, Zurich, Switzerland).

\subsection{CHX Release-Profiles}

The in vitro release-profiles of $\mathrm{CHX}$ were determined by suspending $5 \mathrm{mg}$ of dried CHX-loaded/Ca(OH $)_{2}$ microparticles (at formulations of $\mathrm{CHX}: \mathrm{Ca}(\mathrm{OH})_{2} / 25 \mathrm{mg}$ and $\mathrm{CHX}: \mathrm{Ca}(\mathrm{OH})_{2} / 50 \mathrm{mg}$ )

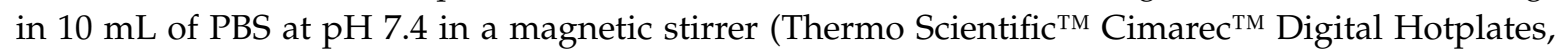
Stockton, CA, USA) maintained at $37^{\circ} \mathrm{C}$. The amount of $\mathrm{CHX}$ released from the microparticles were analyzed spectrophotometrically (UV-1700 Pharma Spec UV-VIS Spectrophotometer, Shimadzu, Japan) at $289 \mathrm{~nm}$ at predetermined time-intervals up to 15 days $(\mathrm{n}=13)$. For the ex vivo characterization of CHX-release profiles from $\mathrm{CHX}: \mathrm{Ca}(\mathrm{OH})_{2} / 25 \mathrm{mg}$ and $\mathrm{CHX}: \mathrm{Ca}(\mathrm{OH})_{2} / 50 \mathrm{mg}$ microparticles delivered to dentin-substrates; oval-shaped filter-paper strips (Whatman PTFE membrane filters; pore size:0.45 $\mu \mathrm{m}$ ) $(8 \mathrm{~mm} \times 5 \mathrm{~mm})$ were prepared and placed on the exposed surfaces of the microparticles-loaded dentin-substrates, just enough to cover the surface. The other exposed areas not covered by the filter paper were sealed with water-proof nail varnish in order to standardize the area for CHX-release. The entire set-up was placed inside a container having $10 \mathrm{~mL}$ of PBS (pH 7.4) (Figure 2e). The amount of $\mathrm{CHX}$ released from microparticles applied to the dentin-substrates through the filter paper to the external PBS release medium was detected by analyzing the PBS spectrophotometrically over pre-determined time-intervals $(n=13)$. Experiments were performed in duplicates and the $\% \mathrm{CHX}$ release was calculated as mean ( \pm standard deviation).

\subsection{Statistical Analysis}

Data were presented as mean \pm standard deviation values and the statistical analysis was done using ANOVA followed by Tukey-Kramer post-hoc test at a chosen significance-level of $p \leq 0.05$.

\section{Results}

\subsection{Morphological Features}

The $z$-average diameter, surface-charge and PDI of the $\mathrm{Ca}(\mathrm{OH})_{2} /$ Blank and CHX-loaded $/ \mathrm{Ca}(\mathrm{OH})_{2}$ microparticles determined by DLS are indicated in Table 1 . The synthesis of the $\mathrm{Ca}(\mathrm{OH})_{2} /$ Blank and the $\mathrm{CHX}$-loaded $/ \mathrm{Ca}(\mathrm{OH})_{2}$ microparticles by aqueous chemical-precipitation method has resulted in particle-size ranging from $1.4 \pm 0.3 \mu \mathrm{m}$ to $5.3 \pm 0.2 \mu \mathrm{m}$. A significant decrease in particle-size was observed upon incorporation of different amounts of CHX (25 and $50 \mathrm{mg})$. Interestingly, the low $\zeta$-potential of $\mathrm{Ca}(\mathrm{OH})_{2} /$ Blank $(+2.19 \pm 0.4 \mathrm{mV})$ was raised to $+23.52 \pm 4.5 \mathrm{mV}$ and $+35.97 \pm 8.6 \mathrm{mV}$ 
respectively, upon increasing $\mathrm{CHX}$ incorporation. The microparticles exhibited PDI values ranging from $0.789 \pm 0.038$ to $0.319 \pm 0.093$, exhibiting a negative-shift with escalating addition of CHX and positive-shift with the increasing particle size.

Table 1. Mean \pm standard deviation of microparticles size (z-average), polydispersity index (PDI), percentage $(\%)$ encapsulation efficiency (EE), percentage (\%) drug loading (DL) and percentage (\%) microparticles recovery of the unloaded $\mathrm{Ca}(\mathrm{OH})_{2} / \mathrm{Blank}$ and $\mathrm{CHX}$-loaded $/ \mathrm{Ca}(\mathrm{OH})_{2}$ microparticles (at the formulations of $\mathrm{CHX}: \mathrm{Ca}(\mathrm{OH})_{2} / 25 \mathrm{mg}$ and $\mathrm{CHX}: \mathrm{Ca}(\mathrm{OH})_{2} / 50 \mathrm{mg}$ ).

\begin{tabular}{|c|c|c|c|c|c|c|}
\hline Formulations & $\begin{array}{c}z \text {-Average } \\
\text { Diameter } \\
(\mu \mathrm{m})\end{array}$ & $\begin{array}{c}\text { Zeta } \\
\text { Potential (乙) } \\
(\mathrm{mV})\end{array}$ & $\begin{array}{l}\text { Polydispersity } \\
\text { Index (PDI) }\end{array}$ & $\begin{array}{c}\text { Encapsulation } \\
\text { Efficiency } \\
\text { EE (\%) }\end{array}$ & $\begin{array}{c}\text { Drug } \\
\text { Loading } \\
\text { (DL) (\%) }\end{array}$ & $\begin{array}{c}\text { Microparticle } \\
\text { Recovery } \\
(\%)\end{array}$ \\
\hline $\mathrm{Ca}(\mathrm{OH})_{2} /$ Blank & & $2.19 \pm 0.4^{\mathrm{A}}$ & $0.789 \pm$ & - & - & $40.26 \pm 2.6^{\mathrm{A}}$ \\
\hline $\mathrm{CHX}: \mathrm{Ca}(\mathrm{OH})_{2} / 25 \mathrm{mg}$ & $1.8 \pm$ & $23.52 \pm 4.5^{\mathrm{B}}$ & $0.347 \pm 0.010^{B}$ & $39.16 \pm 1.6^{\mathrm{A}}$ & $8.80 \pm 6.1^{\mathrm{A}}$ & $38.05 \pm$ \\
\hline $\mathrm{CHX}: \mathrm{Ca}(\mathrm{OH})_{2} / 50 \mathrm{mg}$ & $1.4 \pm 0.3^{\mathrm{B}}$ & $35.97 \pm 8.6^{C}$ & $0.319 \pm 0.093^{\mathrm{B}}$ & $62.34 \pm 2.4^{\mathrm{B}}$ & $20.53 \pm 3.4^{B}$ & $30.78 \pm 1.9^{\mathrm{B}}$ \\
\hline
\end{tabular}

Groups with different superscript letters are statistically significant $(P \leq 0.05)$ within each column.Statistical analysis was done with one-way ANOVA followed by Tukey-Kramer post-hoc test.

Representative SEM and TEM micrographs of the unloaded $\mathrm{Ca}(\mathrm{OH})_{2}\left[\mathrm{Ca}(\mathrm{OH})_{2} / \mathrm{Blank}\right]$ and the CHX-loaded $/ \mathrm{Ca}(\mathrm{OH})_{2}$ microparticles are shown in Figure 3a-c,f indicating successful synthesis of microparticles with less agglomeration. The $\mathrm{Ca}(\mathrm{OH})_{2}$ /Blank-microparticles displayed uniform particle-distribution with hexagonally-plated regularly-shaped appearance (Figure 3a). Upon addition of $\mathrm{CHX}$, the $\mathrm{CHX}$-loaded $/ \mathrm{Ca}(\mathrm{OH})_{2}$ microparticles were spherical-shaped with smooth texture with their size smaller than that of the unloaded $\mathrm{Ca}(\mathrm{OH})_{2} /$ Blank microparticles (Figure 3b,c and Table 1). An even dent-like impression was observed on the surface of CHX-loaded $/ \mathrm{Ca}(\mathrm{OH})_{2}$ microparticles as shown in Figure 3b,c. Representative EDX-SEM elemental-composition spectral characterization of the $\mathrm{Ca}(\mathrm{OH})_{2}$ / Blank showed only the $\mathrm{Ca} / \mathrm{O}$ signals confirming the presence of $\mathrm{Ca}(\mathrm{OH})_{2}$ (Figure 3d) whereas that of the $\mathrm{CHX}: \mathrm{Ca}(\mathrm{OH})_{2} / 50 \mathrm{mg}$-microparticles consisted of chlorine, nitrogen and carbon (the elements confirming the presence of $\mathrm{CHX}$ ) apart from the $\mathrm{Ca} / \mathrm{O}$ signals (Figure 3e). Therefore, EDX data confirmed the presence of $\mathrm{CHX}$ on the surface of the $\mathrm{CHX}$-loaded $/ \mathrm{Ca}(\mathrm{OH})_{2}$ formulations. Similar information on the morphology of the $\mathrm{Ca}(\mathrm{OH})_{2}$ particles have been obtained from TEM investigations, revealing numerous "rounded-deposits" on the microparticle surface (Figure 3f). TEM results were in agreement with the SEM and DLS data. 


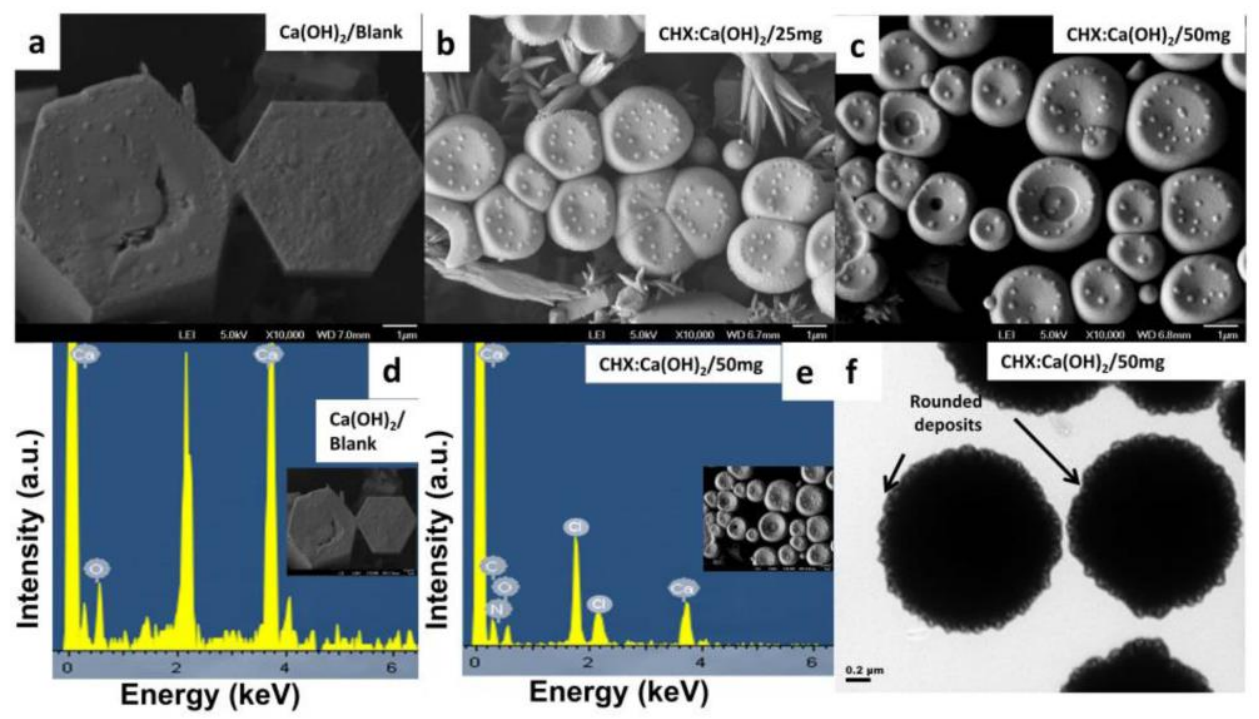

Figure 3. Representative SEM images showing the morphology of (a) the unloaded $\mathrm{Ca}(\mathrm{OH})_{2}$ microparticles $\left[\mathrm{Ca}(\mathrm{OH})_{2} /\right.$ Blank]; $(\mathbf{b}, \mathbf{c})$ the $\mathrm{CHX}$-loaded $/ \mathrm{Ca}(\mathrm{OH})_{2}$ microparticles at the formulations of $\mathrm{CHX}: \mathrm{Ca}(\mathrm{OH})_{2} / 25 \mathrm{mg}$ and $\mathrm{CHX}: \mathrm{Ca}(\mathrm{OH})_{2} / 50 \mathrm{mg}$ respectively. $\mathrm{Ca}(\mathrm{OH})_{2} /$ Blank-microparticles (a) were hexagonal in shape; whereas the $\mathrm{CHX}: \mathrm{Ca}(\mathrm{OH})_{2} / 25 \mathrm{mg}(\mathbf{b})$ and the $\mathrm{CHX}: \mathrm{Ca}(\mathrm{OH})_{2} / 50 \mathrm{mg}$ (c) microparticles exhibited spherical shape with distinctly visible "rounded deposits" on the microparticles surface (d,e). Representative EDX-SEM elemental-composition spectral characterization of the (d) the unloaded $\mathrm{Ca}(\mathrm{OH})_{2}$ microparticles $\left[\mathrm{Ca}(\mathrm{OH})_{2} /\right.$ Blank] showing only the $\mathrm{Ca} / \mathrm{O}$ signals confirmed the presence of $\mathrm{Ca}(\mathrm{OH})_{2}$ in their structure and (e) the $\mathrm{CHX}: \mathrm{Ca}(\mathrm{OH})_{2} / 50 \mathrm{mg}$ displaying the presence of the elements chlorine, nitrogen and carbon, confirmed the presence of these elements constituting $\mathrm{CHX}$, apart from the $\mathrm{Ca} / \mathrm{O}$ signals which again substantiated the presence of $\mathrm{Ca}(\mathrm{OH})_{2}$. (f) Selected high magnification TEM image of the $\mathrm{CHX}: \mathrm{Ca}(\mathrm{OH})_{2} / 50 \mathrm{mg}$ microparticles confirming the spherical morphology and the prominent "rounded-deposits" seen evenly distributed on the surface of microparticles.

\subsection{Encapsulation-Efficiency and Drug-Loading}

The percentage (\%) of drug encapsulation-efficiency (EE), drug-loading (DL) and particle-recovery of the $\mathrm{Ca}(\mathrm{OH})_{2} /$ Blank and the $\mathrm{CHX}$-loaded $/ \mathrm{Ca}(\mathrm{OH})_{2}$ microparticles (at formulations of $\mathrm{CHX}: \mathrm{Ca}(\mathrm{OH})_{2} / 25 \mathrm{mg}$ and $\left.\mathrm{CHX}: \mathrm{Ca}(\mathrm{OH})_{2} / 50 \mathrm{mg}\right)$ are shown in Table 1 . The \% EE has shown a significant increase from $39.16 \% \pm 1.6 \%$ to $62.34 \% \pm 2.4 \%$ with the increasing supplementation of CHX from 25 to $50 \mathrm{mg}$. Initial CHX addition of $25 \mathrm{mg}$ resulted in a $\%$ DL of $8.80 \% \pm 6.1 \%$ whereas further increase in CHX-incorporation has increased the \% DL reaching a value of $20.53 \% \pm 3.4 \%$. A positive-shift in the \% EE values could be noticed with a subsequent increase in the \% DL. Therefore, the highest $\% \mathrm{EE}(62.34 \% \pm 2.4 \%)$ was achieved with a DL of $20.53 \% \pm 3.4 \%$ (Table 1$)$. The percentage (\%) microparticle recovery values of the $\mathrm{Ca}(\mathrm{OH})_{2} /$ Blank has shown to be $40.26 \% \pm 2.6 \%$ whereas CHX-inclusion resulted in values of about $38.05 \% \pm 3.5 \%$ and $30.78 \% \pm 1.9 \%$ respectively.

\subsection{Spectral Analyses}

The FTIR spectra of the $\mathrm{Ca}(\mathrm{OH})_{2} /$ Blank and the $\mathrm{CHX}$-loaded/Ca(OH $)_{2}$ microparticles are shown in Figure 4a. The vibrational-bands observed at $1460 \mathrm{~cm}^{-1}$ confirms the presence of $\mathrm{Ca}(\mathrm{OH})_{2}$ in all $\mathrm{CHX}: \mathrm{Ca}(\mathrm{OH})_{2}$ formulations and corresponds to slight carbonation of $\mathrm{Ca}(\mathrm{OH})_{2}$ due to mixing with $\mathrm{KBr}$ powder in the air as mentioned in previous studies [24]. The sharp peak at $3647-3649 \mathrm{~cm}^{-1}$ attribute to $\mathrm{OH}^{-}$stretching of the solid $\mathrm{Ca}(\mathrm{OH})_{2}$ crystals and the intensity of this peak has shown to diminish upon escalating $\mathrm{CHX}$-incorporation to the $\mathrm{CHX}: \mathrm{Ca}(\mathrm{OH})_{2}$ microparticles. The interaction between the amine $\left(-\mathrm{NH}_{2}\right)$ groups in $\mathrm{CHX}$ and the hydroxyl $(-\mathrm{OH})$ groups present in $\mathrm{Ca}(\mathrm{OH})_{2}$ has resulted in the binding of $\mathrm{CHX}$ to the $\mathrm{Ca}(\mathrm{OH})_{2}$ carrier [25]. The FTIR spectra of pure $\mathrm{CHX}$ has been shown for 
reference exhibiting characteristic peaks at $2947 \mathrm{~cm}^{-1}, 3325 \mathrm{~cm}^{-1}$ and $1093 \mathrm{~cm}^{-1}$ for C-H, N-H and $\mathrm{C}-\mathrm{N}$ respectively. The above-mentioned fingerprint peaks specific to $\mathrm{CHX}$ can be observed in all the $\mathrm{CHX}$-loaded $/ \mathrm{Ca}(\mathrm{OH})_{2}$ formulations as shown in Figure 4a. These results confirm effective inclusion of $\mathrm{CHX}$ in the $\mathrm{Ca}(\mathrm{OH})_{2}$ carrier. Since this procedure involves preparation of $\mathrm{CHX}$-loaded $/ \mathrm{Ca}(\mathrm{OH})_{2}$ microparticles by a wet method, few other peaks at $1650 \mathrm{~cm}^{-1}, 1700 \mathrm{~cm}^{-1}$ have also been detected, that could be due to the presence of residual Triton X-100 in the reaction system [26]. The characteristic peak of both $\mathrm{CHX}$ and $\mathrm{Ca}(\mathrm{OH})_{2}$ seen in the FTIR spectra of the $\mathrm{CHX}: \mathrm{Ca}(\mathrm{OH})_{2}$ formulations indicates the presence of $\mathrm{CHX}$ in $\mathrm{CHX}: \mathrm{Ca}(\mathrm{OH})_{2}$ particles and re-confirms the results obtained by SEM and TEM.
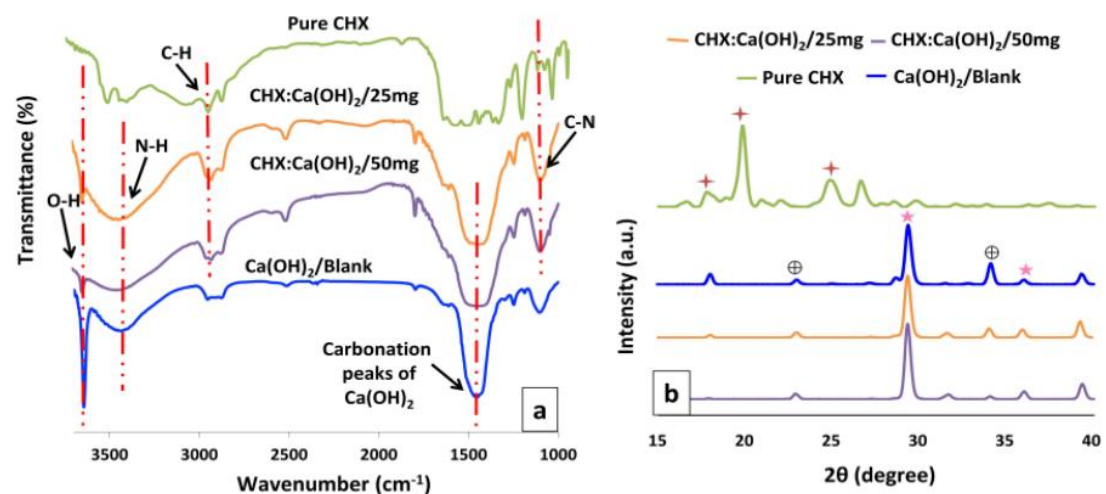

\begin{tabular}{|cc|}
\hline Peak position $\left(\mathrm{cm}^{-1}\right)$ & Assignment \\
$1460 \mathrm{~cm}^{-1}$ & $\begin{array}{c}\text { Indicates presence of } \mathrm{Ca}(\mathrm{OH})_{2} \\
\text { OH- stretching of } \mathrm{Ca}(\mathrm{OH})_{2} \\
3647-3649 \mathrm{~cm}^{-1}\end{array}$ \\
& $\begin{array}{c}\text { C-H bending of } \mathrm{CHX} \text {, interaction } \\
\text { between } \mathrm{NH}_{2} \text { groups of } \mathrm{CHX} \text { and }\end{array}$ \\
$2947 \mathrm{~cm}^{-1}$ & $-\mathrm{OH}$ groups present in water \\
& $\mathrm{N}-\mathrm{H}$ bending of $\mathrm{CHX}$ \\
$3325 \mathrm{~cm}^{-1}$ & C-N bending of $\mathrm{CHX}$ \\
$1093 \mathrm{~cm}^{-1}$ & Residual Triton $\mathrm{X}-100$ \\
$1650 \mathrm{~cm}^{-1}, 1700 \mathrm{~cm}^{-1}$ & \\
\hline
\end{tabular}

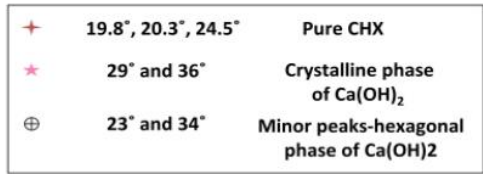

Figure 4. (a) Representative FTIR showing the vibrational-bands obtained for the pure Chlorhexidine $(\mathrm{CHX})$, the $\mathrm{Ca}(\mathrm{OH})_{2}$ /Blank microparticles and the $\mathrm{CHX}$-loaded/Ca(OH $)_{2}$ microparticles at the formulations of $\mathrm{CHX}: \mathrm{Ca}(\mathrm{OH})_{2} / 25 \mathrm{mg}$ and $\mathrm{CHX}: \mathrm{Ca}(\mathrm{OH})_{2} / 50 \mathrm{mg}$ respectively. The FTIR data confirms the evidence of $\mathrm{CHX}$ inclusion in the $\mathrm{CHX}$-loaded $/ \mathrm{Ca}(\mathrm{OH})_{2}$ microparticles. The vibrational-bands observed at $1460 \mathrm{~cm}^{-1}$ confirms the presence of $\mathrm{Ca}(\mathrm{OH})_{2}$ and the presence of peak at $3647-3649 \mathrm{~cm}^{-1}$ attribute to $\mathrm{OH}^{-}$stretching of the solid $\mathrm{Ca}(\mathrm{OH})_{2}$ crystals in all formulations of $\mathrm{CHX}$-loaded $/ \mathrm{Ca}(\mathrm{OH})_{2}$ microparticles. The fingerprint peaks specific to CHX shows characteristic peaks at $2947 \mathrm{~cm}^{-1}$, $3325 \mathrm{~cm}^{-1}$ and $1093 \mathrm{~cm}^{-1}$ for $\mathrm{C}-\mathrm{H}, \mathrm{N}-\mathrm{H}$ and $\mathrm{C}-\mathrm{N}$ respectively, observed in both formulations of $\mathrm{CHX}$-loaded $/ \mathrm{Ca}(\mathrm{OH})_{2}$. The interaction between the amine $\left(-\mathrm{NH}_{2}\right)$ groups in $\mathrm{CHX}$ and the hydroxyl $(-\mathrm{OH})$ groups present in $\mathrm{Ca}(\mathrm{OH})_{2}$ has resulted in the binding of $\mathrm{CHX}$ to the $\mathrm{Ca}(\mathrm{OH})_{2}$ carrier. Accordingly, the $\mathrm{N}-\mathrm{H}$ bend $\left(3325 \mathrm{~cm}^{-1}\right)$ was notably flatter/wider and $\mathrm{C}-\mathrm{N}$ peak $\left(1093 \mathrm{~cm}^{-1}\right)$ became deeper upon CHX inclusion. The positions of the FTIR peak frequencies and their corresponding assignment in the $\mathrm{Ca}(\mathrm{OH})_{2}$ /Blank, pure Chlorhexidine $(\mathrm{CHX})$ and $\mathrm{CHX}$-loaded $/ \mathrm{Ca}(\mathrm{OH})_{2}$ microparticles at formulations of $\mathrm{CHX}: \mathrm{Ca}(\mathrm{OH})_{2} / 25 \mathrm{mg}$ and $\mathrm{CHX}: \mathrm{Ca}(\mathrm{OH})_{2} / 50 \mathrm{mg}$ respectively have been indicated in the table (left). (b) Representative X-ray diffractograms (XRD) of pure Chlorhexidine (CHX), the $\mathrm{Ca}(\mathrm{OH})_{2}$ / Blank microparticles, and the $\mathrm{CHX}$-loaded/Ca(OH $)_{2}$ microparticles at the formulations of $\mathrm{CHX}: \mathrm{Ca}(\mathrm{OH})_{2} / 25 \mathrm{mg}$ and $\mathrm{CHX}: \mathrm{Ca}(\mathrm{OH})_{2} / 50 \mathrm{mg}$ are displayed respectively. The typical XRD peaks of $\mathrm{Ca}(\mathrm{OH})_{2}$ present the diffraction angles at $29^{\circ}$ and $36^{\circ}$ indicating the crystalline phase of $\mathrm{Ca}(\mathrm{OH})_{2}$ in the all formulations. Pure CHX showed clear peaks at $2 \theta$ of $19.8^{\circ}, 20.3^{\circ}$ and $24.5^{\circ}$ and the absence of these characteristic peaks in the $\mathrm{CHX}$-loaded $/ \mathrm{Ca}(\mathrm{OH})_{2}$ formulations confirmed uniform $\mathrm{CHX}$ dispersion in the structure of the $\mathrm{CHX}$-loaded/Ca(OH $)_{2}$ microparticles. The positions of the XRD peaks and their corresponding assignment in the $\mathrm{Ca}(\mathrm{OH})_{2}$ /Blank microparticles, pure Chlorhexidine (CHX), $\mathrm{CHX}$-loaded $/ \mathrm{Ca}(\mathrm{OH})_{2}$ microparticles have been indicated in the table (right). 
The XRD profiles of the $\mathrm{Ca}(\mathrm{OH})_{2} /$ Blank and the $\mathrm{CHX}: \mathrm{Ca}(\mathrm{OH})_{2}$ microparticles are shown in Figure $4 \mathrm{~b}$. The typical XRD peaks of $\mathrm{Ca}(\mathrm{OH})_{2}$ present the diffraction angles at $29^{\circ}$ and $36^{\circ}$ indicating the crystalline phase of $\mathrm{Ca}(\mathrm{OH})_{2}$ in all the formulations [21]. However, some minor peaks representing the hexagonal phases at $23^{\circ}$ and $34^{\circ}$ were also noticed [27]. Pure CHX has shown clear peaks at $2 \theta$ of $19.8^{\circ}, 20.3^{\circ}$ and $24.5^{\circ}$ (shown for reference). The absence of these characteristic peaks specific to $\mathrm{CHX}$ at $19.8^{\circ}, 20.3^{\circ}$ and $24.5^{\circ}$ in the $\mathrm{CHX}: \mathrm{Ca}(\mathrm{OH})_{2}$ formulations confirmed significant incorporation and effective loading of $\mathrm{CHX}$ in the structure of the formed $\mathrm{CHX}: \mathrm{Ca}(\mathrm{OH})_{2}$ microparticles. The uniform dispersion of $\mathrm{CHX}$ in $\mathrm{CHX}: \mathrm{Ca}(\mathrm{OH})_{2}$ carrier has contributed to the disappearance of these peaks. It can also be observed that except for $\mathrm{Ca}(\mathrm{OH})_{2}$ and $\mathrm{CHX}$ no obvious peak has resulted indicating reproducibility and uniqueness of the synthesis procedure. XRD results confirmed the successful inclusion of $\mathrm{CHX}$ in the $\mathrm{CHX}: \mathrm{Ca}(\mathrm{OH})_{2}$ formulations and are in agreement with the data obtained from FTIR analysis.

\subsection{Thermal Properties}

Representative TGA thermograms showing the percentage weight loss of the $\mathrm{Ca}(\mathrm{OH})_{2} /$ Blank, the CHX-loaded $/ \mathrm{Ca}(\mathrm{OH})_{2}$ microparticles and pure $\mathrm{CHX}$ are shown in Figure 5a. It has been widely recognized that the decomposition temperature of $\mathrm{Ca}(\mathrm{OH})_{2}$ occurs between $350{ }^{\circ} \mathrm{C}$ and $550{ }^{\circ} \mathrm{C}$ [28]. The TGA curve of the pure CHX (shown for reference), demonstrated mass-loss around $100{ }^{\circ} \mathrm{C}$ as indicated in previous studies [29]. From the obtained TGA curves, the $\mathrm{Ca}(\mathrm{OH})_{2} /$ Blank microparticles has undergone decomposition at approximately $350-400{ }^{\circ} \mathrm{C}$ whereas $\mathrm{CHX}$ encapsulation shifted the decomposition to higher temperatures $\left(\sim 450-500{ }^{\circ} \mathrm{C}\right)$. It could also be inferred that the entrapment of $\mathrm{CHX}$ in $\mathrm{Ca}(\mathrm{OH})_{2}$ microparticles resulted in structural changes in the microparticles. DSC studies were analyzed to understand the nature of the drug in the particle carrier (Figure 5b). The physical state of $\mathrm{CHX}$ in the CHX-loaded $/ \mathrm{Ca}(\mathrm{OH})_{2}$ microparticles would also influence its release characteristics. To probe this effect, DSC measurements were performed on the $\mathrm{Ca}(\mathrm{OH})_{2} /$ Blank, the $\mathrm{CHX}$-loaded $/ \mathrm{Ca}(\mathrm{OH})_{2}$ microparticles (at formulations of $\mathrm{CHX}: \mathrm{Ca}(\mathrm{OH})_{2} / 25 \mathrm{mg}$ and $\mathrm{CHX}: \mathrm{Ca}(\mathrm{OH})_{2} / 50 \mathrm{mg}$ ) and pure CHX. From the DSC curves displayed in Figure $5 \mathrm{~b}$, the endotherm peaks of $\mathrm{Ca}(\mathrm{OH}) 2 /$ Blank were observed at $\sim 222.38{ }^{\circ} \mathrm{C}$. Upon incorporation of $\mathrm{CHX}$, the endothermic peaks of $\mathrm{CHX}: \mathrm{Ca}(\mathrm{OH})_{2} / 25 \mathrm{mg}$ and $\mathrm{CHX}: \mathrm{Ca}(\mathrm{OH})_{2} / 50 \mathrm{mg}$ have been displaced to a temperature of $\sim 252.28^{\circ} \mathrm{C}$ and $\sim 228.40{ }^{\circ} \mathrm{C}$ respectively. The endotherm of pure $\mathrm{CHX}\left(\sim 135.45^{\circ} \mathrm{C}\right)$ was not detected in the microparticle formulations. Absence of the detectable $\mathrm{CHX}$ domains in the spectra of $\mathrm{CHX}: \mathrm{Ca}(\mathrm{OH})_{2}$ formulations indicated uniform $\mathrm{CHX}$ dispersion in the $\mathrm{CHX}: \mathrm{Ca}(\mathrm{OH})_{2}$ carrier and therefore, corroborated the XRD findings. Hence, the displacement of the endothermic peaks of $\mathrm{CHX}$-loaded/Ca(OH$)_{2}$ microparticles mainly indicates successful $\mathrm{CHX}$-incorporation in the formulations. 

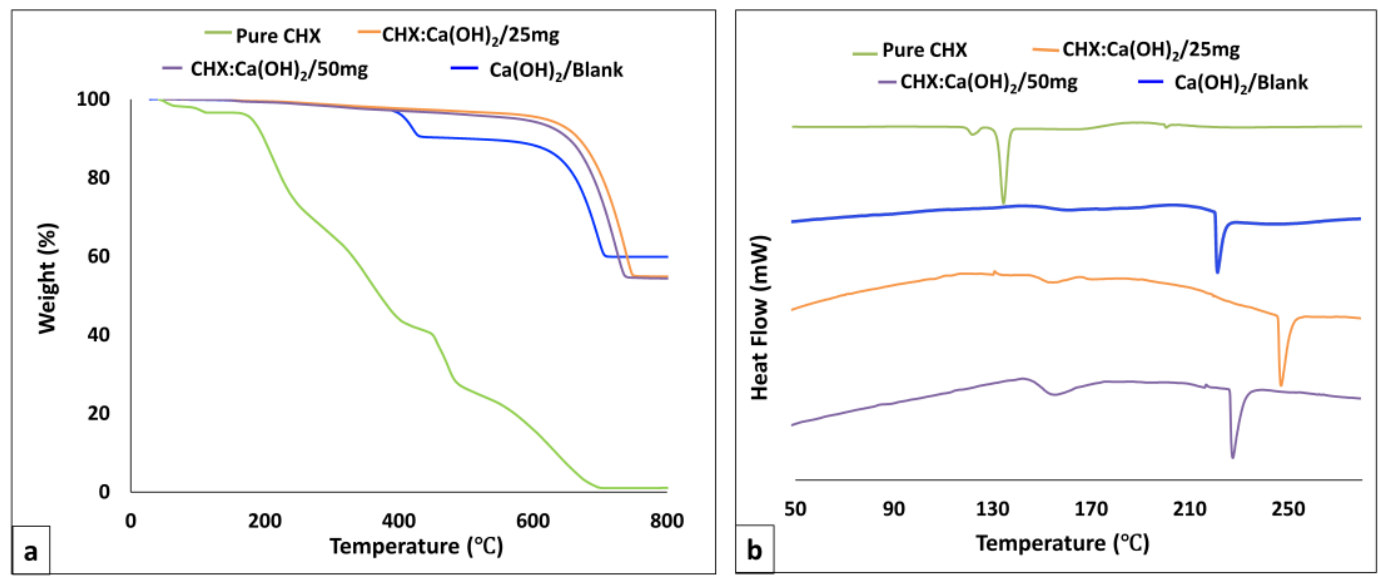

Figure 5. (a) Representative Thermogravimetric Analysis (TGA) profiles displaying the spectra of the pure Chlorhexidine $(\mathrm{CHX})$, the unloaded $\mathrm{Ca}(\mathrm{OH})_{2}$ microparticles $\left[\mathrm{Ca}(\mathrm{OH})_{2} / \mathrm{Blank}\right]$, and the $\mathrm{CHX}$-loaded $/ \mathrm{Ca}(\mathrm{OH})_{2}$ microparticles at the formulations of $\mathrm{CHX}: \mathrm{Ca}(\mathrm{OH})_{2} / 25 \mathrm{mg}$ and $\mathrm{CHX}: \mathrm{Ca}(\mathrm{OH})_{2} / 50 \mathrm{mg}$ respectively. The $\mathrm{Ca}(\mathrm{OH})_{2} /$ Blank microparticles showed decomposition at approximately $350-400{ }^{\circ} \mathrm{C}$. Pure $\mathrm{CHX}$ has demonstrated weight-loss at $\sim 100{ }^{\circ} \mathrm{C}$ whereas its entrapment in $\mathrm{Ca}(\mathrm{OH})_{2}$ microparticles shifted degradation to higher temperatures $\left(\sim 450-500{ }^{\circ} \mathrm{C}\right)$. Therefore, entrapment procedure has resulted in structural changes in $\mathrm{CHX}$-loaded $/ \mathrm{Ca}(\mathrm{OH})_{2}$ microparticles (b) Representative DSC thermograms showing the spectra of the pure Chlorhexidine (CHX), the $\mathrm{Ca}(\mathrm{OH})_{2}$ / Blank microparticles, and the $\mathrm{CHX}$-loaded/Ca(OH $)_{2}$ microparticles at the formulations of $\mathrm{CHX}: \mathrm{Ca}(\mathrm{OH})_{2} / 25 \mathrm{mg}$ and $\mathrm{CHX}: \mathrm{Ca}(\mathrm{OH})_{2} / 50 \mathrm{mg}$ respectively. The endotherm peaks of $\mathrm{Ca}(\mathrm{OH})_{2} / \mathrm{Blank}$ were observed at $\sim 222.38^{\circ} \mathrm{C}$. Upon $\mathrm{CHX}$ incorporation, $\mathrm{CHX}$ endotherm peaks were displaced to a temperature of $\sim 250.28{ }^{\circ} \mathrm{C}$ and $\sim 235.40{ }^{\circ} \mathrm{C}$ in $\mathrm{CHX}: \mathrm{Ca}(\mathrm{OH})_{2} / 25 \mathrm{mg}$ and $\mathrm{CHX}: \mathrm{Ca}(\mathrm{OH})_{2} / 50 \mathrm{mg}$, respectively, confirming the presence of $\mathrm{CHX}$ in these formulations. Absence of the detectable $\mathrm{CHX}$ domains $\left(\sim 136^{\circ} \mathrm{C}\right)$ in the spectra of microparticles indicated uniform $\mathrm{CHX}$ dispersion in the $\mathrm{Ca}(\mathrm{OH})_{2}$ carrier.

\subsection{Evaluation of $\mathrm{pH}$}

The $\mathrm{pH}$ values of $\mathrm{Ca}(\mathrm{OH})_{2} /$ Blank and $\mathrm{CHX}$-loaded/Ca $(\mathrm{OH})_{2}$ microparticles (at formulations of $\mathrm{CHX}: \mathrm{Ca}(\mathrm{OH})_{2} / 25 \mathrm{mg}$ and $\left.\mathrm{CHX}: \mathrm{Ca}(\mathrm{OH})_{2} / 50 \mathrm{mg}\right)$ remained consistently high, ranging from 12.5 to 13.06 up to 15 days as displayed in Figure 6a. There was no significant difference between $\mathrm{pH}$ of $\mathrm{Ca}(\mathrm{OH})_{2} /$ Blank and $\mathrm{CHX}$-loaded $/ \mathrm{Ca}(\mathrm{OH})_{2}$ microparticles at all determined time points. The $\mathrm{pH}$ of commercial $\mathrm{Ca}(\mathrm{OH})_{2}$ powder was slightly lower than the microparticles (ranging from $\sim 12$ to 12.5 ) but higher than that of Dycal, which exhibited lowest $\mathrm{pH}$ values ranging from $~ 11.59$ to 12.06 .

\subsection{Cytotoxicity Assay}

The cell-viability of the $\mathrm{Ca}(\mathrm{OH})_{2} /$ Blank and $\mathrm{CHX}$-loaded/Ca $(\mathrm{OH})_{2}$ microparticles (at formulations of $\mathrm{CHX}: \mathrm{Ca}(\mathrm{OH})_{2} / 25 \mathrm{mg}$ and $\mathrm{CHX}: \mathrm{Ca}(\mathrm{OH})_{2} / 50 \mathrm{mg}$ ) was $>90 \%$ at all tested concentrations of 20,60 and $100 \mu \mathrm{g} / \mathrm{mL}$ as shown in Figure $6 \mathrm{~b}$. Therefore, particles showed low toxicity to hMSCs at the proposed concentrations. Hence $\mathrm{Ca}(\mathrm{OH})_{2} /$ Blank and both formulations of $\mathrm{CHX}$-loaded $/ \mathrm{Ca}(\mathrm{OH})_{2}$ microparticles are relatively biocompatible to hMSCs during the $24 \mathrm{~h}$ of exposure. The commercial $\mathrm{Ca}(\mathrm{OH})_{2}$ powder also promoted cell proliferation resulting in high cell-viability values (>90\%). However, pure CHX has reduced the viability of the cells in comparison to the microparticles. Dycal has shown strong cytotoxicity at all concentrations resulting in in $<60 \%$ viable cells. 


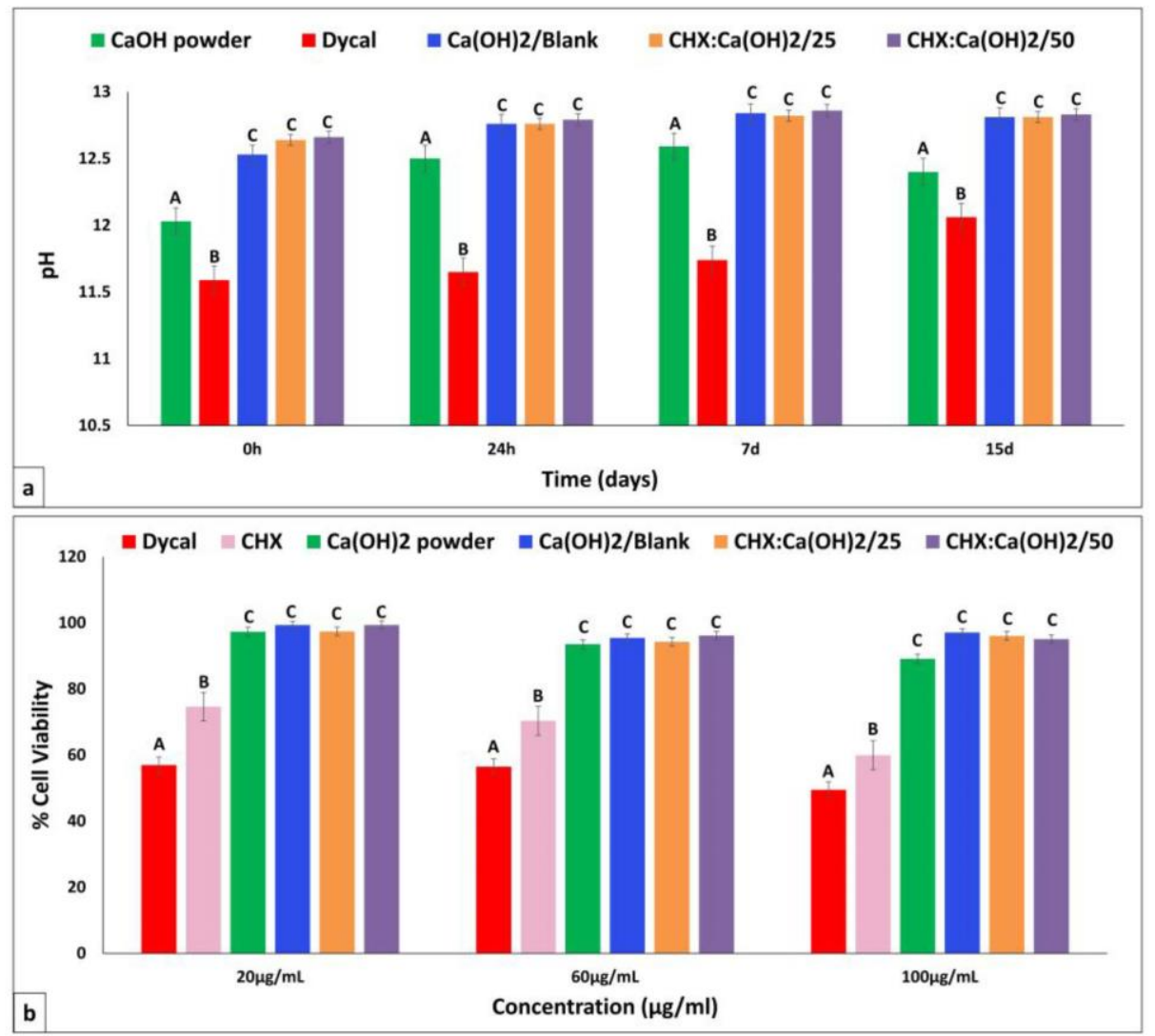

Figure 6. (a) Mean \pm standard deviation of the measured $\mathrm{pH}$ values of the prepared $\mathrm{Ca}(\mathrm{OH})_{2} / \mathrm{Blank}$ microparticles, CHX-loaded/Ca $(\mathrm{OH})_{2}$ microparticles (at formulations of $\mathrm{CHX}: \mathrm{Ca}(\mathrm{OH})_{2} / 25 \mathrm{mg}$ and $\left.\mathrm{CHX}: \mathrm{Ca}(\mathrm{OH})_{2} / 50 \mathrm{mg}\right)$, Dycal and the commercial $\mathrm{Ca}(\mathrm{OH})_{2}$ powder determined at $0 \mathrm{~h}, 24 \mathrm{~h}, 7$ days and 15 days respectively. The $\mathrm{pH}$ values of the prepared microparticles were consistently high ranging from $\sim 12.5$ to $\sim 13.06$ at all specified time points; whereas that of the commercial $\mathrm{Ca}(\mathrm{OH})_{2}$ powder was comparatively lower ranging from $\sim 12$ to 12.5 . No significant difference was observed between $\mathrm{pH}$ of the $\mathrm{Ca}(\mathrm{OH})_{2} /$ Blank and the $\mathrm{CHX}$-loaded $/ \mathrm{Ca}(\mathrm{OH})_{2}$ microparticles. Dycal demonstrated lowest $\mathrm{pH}$ with values ranging from $\sim 11.59$ to $\sim 12.06$. (b) Mean \pm standard deviation of the percentage (\%) cell viability of human mesenchymal stem cells (hMSCs) showing low cytotoxicity profile (>90\%) upon $24 \mathrm{~h}$ of exposure to the different concentrations $(20,60$ and $100 \mu \mathrm{g} / \mathrm{mL})$ of the $\mathrm{Ca}(\mathrm{OH})_{2} / \mathrm{Blank}$ microparticles, the $\mathrm{CHX}$-loaded $/ \mathrm{Ca}(\mathrm{OH})_{2}$ microparticles, and the commercial $\mathrm{Ca}(\mathrm{OH})_{2}$ powder. On the contrary, exposure to Dycal and pure $\mathrm{CHX}$ has reduced the viability of cells. * Groups with different alphabets are statistically significant $(p \leq 0.05)$ within each time point and concentration for $\mathrm{pH}$ and cell viability respectively. ${ }^{*}$ Statistical analysis was done with one-way ANOVA followed by Tukey-Kramer post-hoc test.

\subsection{Bacterial Inhibition Zone}

The diameters of zones of inhibition for E. faecalis and S. mutans in the presence of $\mathrm{Ca}(\mathrm{OH})_{2} /$ Blank and $\mathrm{CHX}$-loaded $/ \mathrm{Ca}(\mathrm{OH})_{2}$ microparticles (at formulations of $\mathrm{CHX}: \mathrm{Ca}(\mathrm{OH})_{2} / 25 \mathrm{mg}$ and $\mathrm{CHX}: \mathrm{Ca}(\mathrm{OH})_{2} / 50 \mathrm{mg}$ ) are shown in Table 2. $\mathrm{CHX}$-loaded $/ \mathrm{Ca}(\mathrm{OH})_{2}$ microparticles have shown activity against both the strains (after $48 \mathrm{~h}$ ) although pure unencapsulated CHX has shown to be more effective than the synthesized $\mathrm{CHX}$-loaded $/ \mathrm{Ca}(\mathrm{OH})_{2}$ microparticles. Dycal and the commercial $\mathrm{Ca}(\mathrm{OH})_{2}$ powder have exhibited reduced antibacterial efficacy than the pure $\mathrm{CHX}$; and the $\mathrm{Ca}(\mathrm{OH})_{2} /$ Blank and $\mathrm{CHX}$-loaded $/ \mathrm{Ca}(\mathrm{OH})_{2}$ microparticles. 
Table 2. Inhibition zone diameters obtained from agar disk diffusion assay with $\mathrm{S}$. mutans and $E$. faecalis in the presence of Dycal, the commercial Ca(OH $)_{2}$ powder, the $\mathrm{Ca}(\mathrm{OH})_{2} /$ Blank microparticles, the different formulations of $\mathrm{CHX}$-loaded $/ \mathrm{Ca}(\mathrm{OH})_{2}$ microparticles and the corresponding unencapsulated $\mathrm{CHX}$ (positive control).

\begin{tabular}{|c|c|c|c|c|c|c|c|}
\hline \multirow{3}{*}{ Bacterial Strains Used } & \multicolumn{7}{|c|}{ Diameters of Inhibition Zones $(\mathrm{cm})^{*}$ Measured at: } \\
\hline & \multirow{2}{*}{$\mathrm{Ca}(\mathrm{OH})_{2} /$ Blank } & \multicolumn{2}{|c|}{ 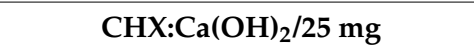 } & \multicolumn{2}{|c|}{$\mathrm{CHX}: \mathrm{Ca}(\mathrm{OH})_{2} / 50 \mathrm{mg}$} & \multirow{2}{*}{ Commercial $\mathrm{Ca}(\mathrm{OH})_{2}$ Powder } & \multirow{2}{*}{ Dycal } \\
\hline & & MP & CHX +ve Control & MP & CHX +ve Control & & \\
\hline S. mutans & $0.72 \pm 0.05^{\mathrm{A}}$ & $1.2 \pm .0 .37^{\mathrm{B}}$ & $2.3 \pm 0.52^{C}$ & $1.8 \pm 0.28^{\mathrm{D}}$ & $2.5 \pm 0.46^{\mathrm{C}}$ & $0.62 \pm 0.18 \mathrm{AD}$ & $0.48 \pm 0.15^{\mathrm{D}}$ \\
\hline E. faecalis & $0.49 \pm 0.13^{\mathrm{A}}$ & $0.95 \pm .0 .24^{\mathrm{B}}$ & $1.4 \pm 0.32^{\mathrm{C}}$ & $1.1 \pm 0.31^{\text {B }}$ & $2.1 \pm 0.37^{\mathrm{D}}$ & $0.46 \pm 0.17^{\mathrm{A}}$ & $0.34 \pm 0.09^{\mathrm{A}}$ \\
\hline
\end{tabular}

Groups with different superscript letters are statistically significant $(P \leq 0.05)$ in each row. Statistical analysis was done with one-way ANOVA followed by Tukey-Kramer post-hoc test.

MP: microparticles; CHX: Chlorhexidine. 


\subsection{Microparticles Application to Dentin-Substrates}

Representative SEM images of dentin-surfaces treated with $\mathrm{CHX}$-loaded $/ \mathrm{Ca}(\mathrm{OH})_{2}$ microparticles carried on water (microparticles/carrier suspension), showed formation of an intact layer of uniformly disseminated spherical-shaped microparticles indicating successful attachment on the exposed dentin-surfaces (Figure 7b,c). Moreover, after the intentional removal of the overlying microparticles layer through micro-brushing and air-blowing, the ability of the microparticles to occlude the open dentinal-tubules of the ultra-high polished dentin-surface can be revealed Figure 7d-g. Even in the absence of such manipulative procedures, microparticles were seen associated to the orifice of the dentinal tubules Figure 7h.

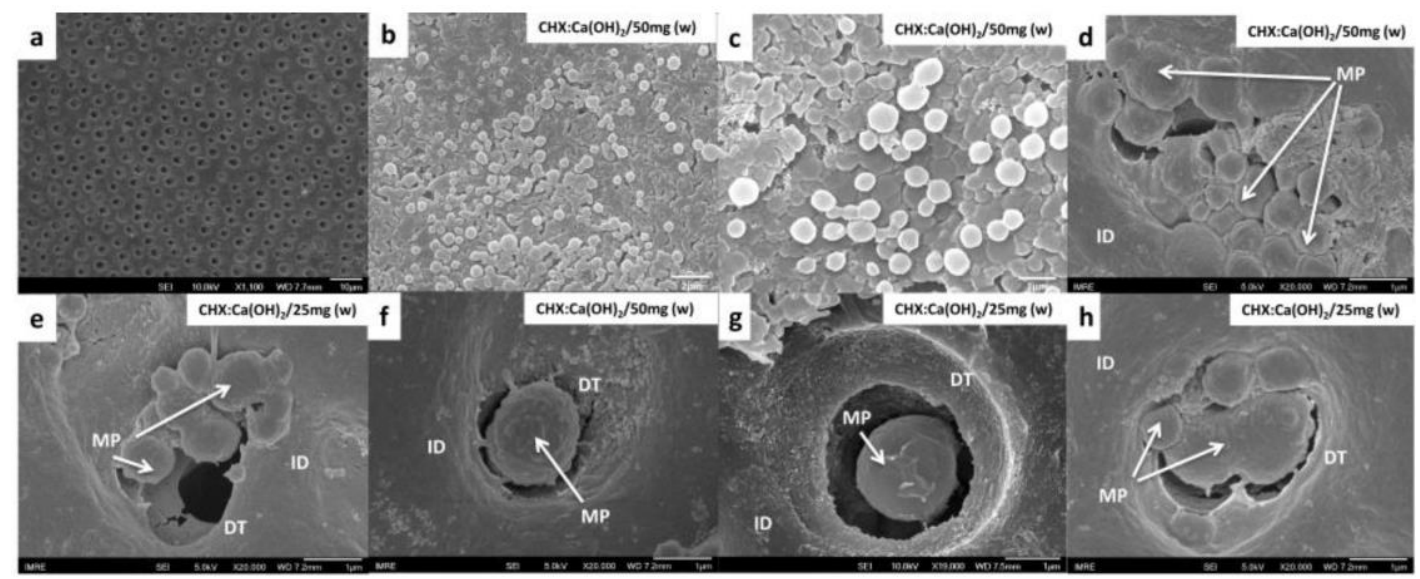

Figure 7. (a) Representative SEM image of the ultra-high polished specimens showing the dentinal tubules structure of the deep dentin (scale: $10 \mu \mathrm{m})$. (b,c) Selected SEM images, at different magnifications, showing the formation of an intact layer of evenly-distributed spherical microparticles attached and covering the prepared dentin surface (scale: $2 \mu \mathrm{m}$ and $1 \mu \mathrm{m}$ respectively). This indicates successful attachment of microparticles on the exposed dentin-surfaces. (d-g) Selected high magnification SEM images, at different magnifications, showing the ability of the microparticles to seal the open dentinal-tubules of the ultra-high polished dentin-surface (scale: $1 \mu \mathrm{m}$ ). (h) SEM image showing the dentinal tubule occlusion of microparticles in the absence of micro-brushing and air-blowing procedures.

\subsection{Biofilm Attachment/Confocal Microscopy Imaging}

Selected confocal microscopy images showing live/dead proportions of S. mutans and E. faecalis are shown in Figure 8. SYTO9-PI staining of biofilms revealed bacterial populations of living cells stained in green and dead cells with compromised cell membrane stained in red. An overlap of the live and dead bacteria produced a yellow to orange color at some locations. Biofilms attached on dentin-specimens treated with the $\mathrm{Ca}(\mathrm{OH})_{2}$ / Blank microparticles showed heavy coverage with dense proportions of live bacteria with few dead bacteria in both bacterial strains (Figure 8a,d). The dentin specimens treated with the $\mathrm{CHX}$-loaded $/ \mathrm{Ca}(\mathrm{OH})_{2}$ microparticles demonstrated escalating effective antibacterial action on $S$. mutans biofilms denoted by the more observable contribution of dead bacteria with low fraction of live bacterial coverage (Figure 8b,c). For the E. faecalis biofilms (Figure 8e,f), attached to the microparticles treated dentin specimens, the fraction of predominant stubborn live cell fluorescence contribution become more expressed compared to the $S$. mutans biofilms. 


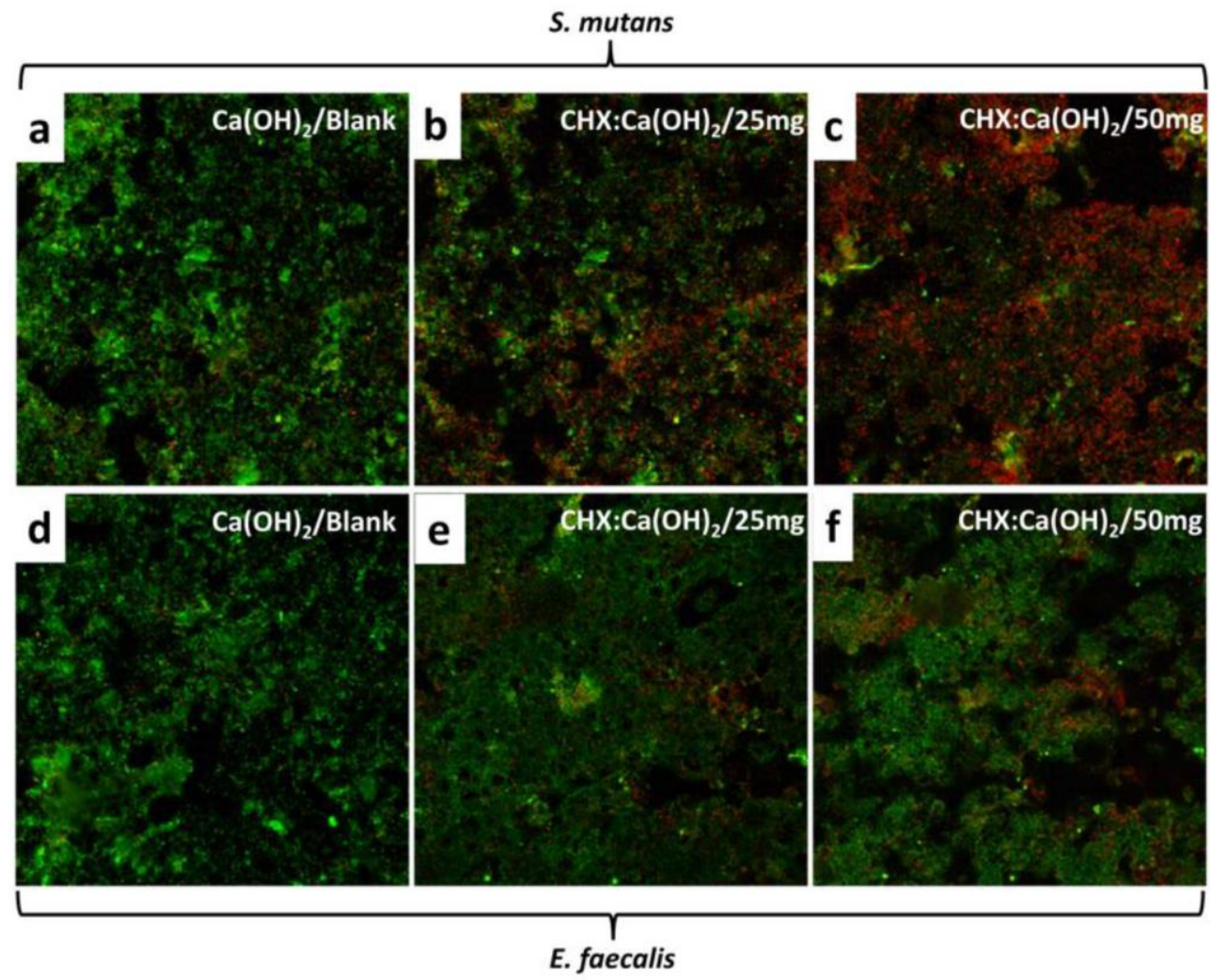

Figure 8. Selected confocal microscopy images showing Live/Dead assay of (a-c) S. mutans and (d-f) E. faecalis attached on dentin specimens treated with the $\mathrm{Ca}(\mathrm{OH})_{2} / \mathrm{Blank}, \mathrm{CHX}: \mathrm{Ca}(\mathrm{OH})_{2} / 25 \mathrm{mg}$ and $\mathrm{CHX}: \mathrm{Ca}(\mathrm{OH})_{2} / 50 \mathrm{mg}$ microparticles, respectively at 3 days (scale: $15 \mu \mathrm{m}$ ). The distinction between live and dead bacterial cells could be noticed in the above images. (a,d) $\mathrm{Ca}(\mathrm{OH})_{2} /$ Blank-treated dentin surfaces showed dense network of live bacterial cells covering the entire surface of treated dentin-surfaces with few dead bacteria in view. $(\mathbf{b}, \mathbf{c})$ The progressive antibacterial efficacy on S. mutans cells was evidenced from the increased red fluorescence contribution with dentin-specimens treated with increasing ratios of $\mathrm{CHX}$-loaded $\mathrm{Ca}(\mathrm{OH})_{2}$ microparticles. (e,f) However, E. faecalis biofilms attached dentin-specimens treated with the $\mathrm{CHX}$-loaded $\mathrm{Ca}(\mathrm{OH})_{2}$ microparticles revealed high coverage of predominant stubborn live cell fluorescence contribution as compared to the S. mutans biofilms.

\subsection{In Vitro CHX-Release Profiles}

From the in vitro CHX release experiment, an initial burst CHX-release was observed for $\sim 1.5$ days followed by a cumulative-release of $86.58 \% \pm 2.1 \%$ and $94.94 \% \pm 1.4 \%$ (at 15 days) for $\mathrm{CHX}$-loaded $/ \mathrm{Ca}(\mathrm{OH})_{2}$ microparticles at formulations of $\mathrm{CHX}: \mathrm{Ca}(\mathrm{OH})_{2} / 25 \mathrm{mg}$ and $\mathrm{CHX}: \mathrm{Ca}(\mathrm{OH})_{2} / 50 \mathrm{mg}$, respectively (Figure 9a). The ex vivo $\mathrm{CHX}$ release-profiles from microparticles (at formulations of $\mathrm{CHX}: \mathrm{Ca}(\mathrm{OH})_{2} / 25 \mathrm{mg}$ and $\mathrm{CHX}: \mathrm{Ca}(\mathrm{OH})_{2} / 50 \mathrm{mg}$ ) delivered to dentin-surfaces followed similar release-kinetics, with the highest cumulative value of $24.89 \% \pm 9.5 \%$ from the $\mathrm{CHX}: \mathrm{Ca}(\mathrm{OH})_{2} / 50 \mathrm{mg}$ microparticles (Figure $9 \mathrm{~b}$ ). 


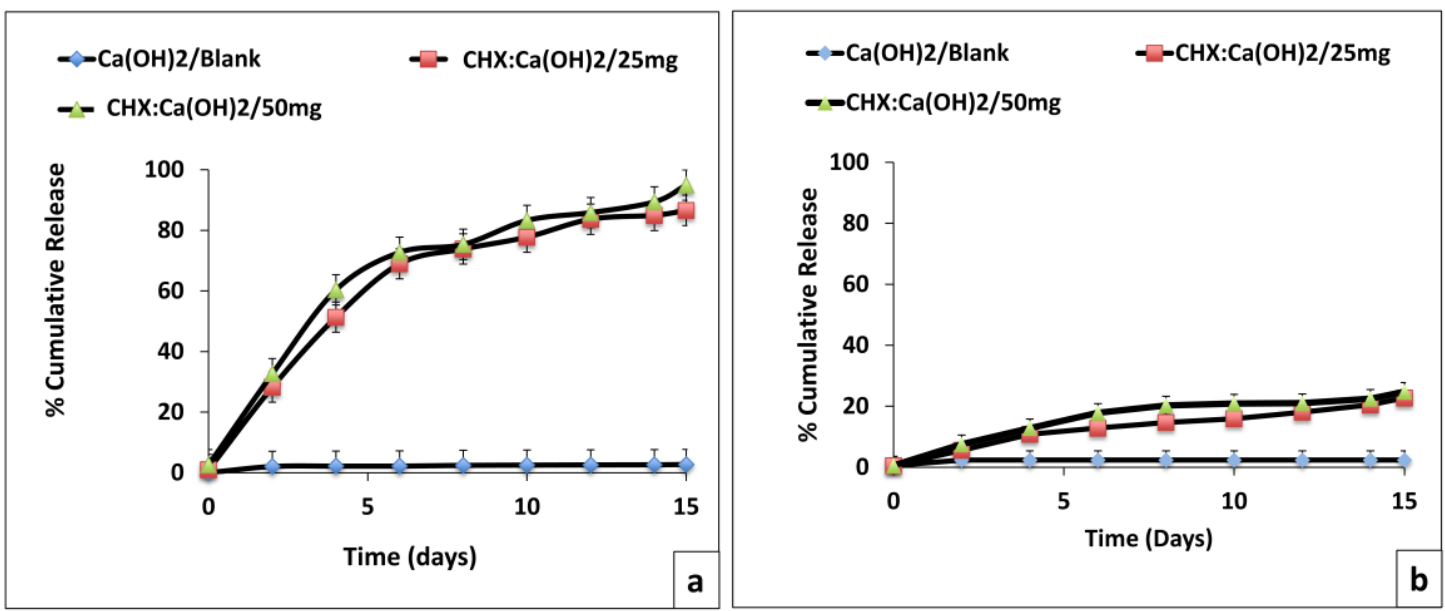

Figure 9. (a) The percentage (\%) of cumulative $\mathrm{CHX}$ in vitro release from the $\mathrm{CHX}$-loaded $/ \mathrm{Ca}(\mathrm{OH})_{2}$ microparticles at $37{ }^{\circ} \mathrm{C}$ in phosphate buffered saline (PBS) at the physiological $\mathrm{pH}$ of 7.4 up to 15 days (in-vitro release-profile). (b) The percentage (\%) of cumulative $\mathrm{CHX}$ ex vivo release from the $\mathrm{CHX}$-loaded $/ \mathrm{Ca}(\mathrm{OH})_{2}$ microparticles delivered to the dentin-substrate (ex-vivo release-profile) in phosphate buffered saline (PBS) at $37^{\circ} \mathrm{C}$ at the physiological $\mathrm{pH}$ of 7.4 up to 15 days. Note: Statistical analysis of $\mathrm{CHX}$-release was done with one-way ANOVA followed by Tukey-Kramer post-hoc test ( $p \leq 0.05$; significant). The $\mathrm{Ca}(\mathrm{OH})_{2}$ /Blank microparticles were used as control.

\section{Discussion}

Despite significant advancement in the field of pulp therapy, the technique and philosophy of pulp capping remains a controversy [30]. Many clinicians have recommended the application of $\mathrm{Ca}(\mathrm{OH})_{2}$ for capping of accidentally injured human pulp [31]. With a longest record of clinical success, the alkalinity and ability to act as an effective pulp-protector still makes $\mathrm{Ca}(\mathrm{OH})_{2}$ a part of the practitioner's armamentarium. Although treatment with $\mathrm{Ca}(\mathrm{OH})_{2}$ has been successful, dentistry has advanced further beyond the realm of traditional pulp-capping materials [32]. Researchers have exploited the properties of antiseptic compounds such as $2 \%$ chlorhexidine ( $\mathrm{CHX}$ ), a pulp-capping disinfectant and non-specific MMPs inhibitor, with an effort to amplify the antimicrobial properties of $\mathrm{Ca}(\mathrm{OH})_{2}$ and to achieve some beneficial synergism [33,34]. Although $2 \% \mathrm{CHX}$ induced mild inflammatory pulp-response upon direct application, its combination with $\mathrm{Ca}(\mathrm{OH})_{2}$ not only eradicated microbes resistant to $\mathrm{Ca}(\mathrm{OH})_{2}$ alone, but also proved to be a successful intracanal medicament $[35,36]$. Accordingly, the synergistic effect of such medications may demand more complex interactions than simply the physical mixture of drugs. Moreover, the use of this combination has not yet been reported as a pulp-capping material. Therefore, in this work, we have formulated CHX-loaded $/ \mathrm{Ca}(\mathrm{OH})_{2}$ microparticles, as a potential pulp-capping material, capable of providing more sustained release of $\mathrm{CHX}$ and thereby highlighting its property of substantivity. The main novelty of the current study lies in the present effort to immensely exploit $\mathrm{Ca}(\mathrm{OH})_{2}$ microparticles as a drug-delivery carrier.

The CHX-loaded/Ca(OH $)_{2}$ microparticles were synthesized by modified aqueous chemical-precipitation method (Figure 1a), owing to mild preparation conditions and feasibility in obtaining microparticles directly in suspension [27]. Microparticles with a unique morphology (Figure 3) were obtained, thereby offering a distinct advantage over other preparation-techniques [37]. Earlier, this simple inexpensive procedure was specifically adapted for fabricating nano-sized $\mathrm{Ca}(\mathrm{OH})_{2}[27,38,39]$. To accommodate our need for a novel pulp-capping material, the procedure was improvised by reducing the amount of surfactant/triton X-100 with simultaneous drug (CHX) addition, targeting to synthesize microparticles with larger $z$-average diameters (Table 1). Moreover, $\mathrm{CHX} / \mathrm{Cl}^{-}$interaction resulting in precipitate formation and therefore, drug wastage has been minimized by addition of non-ionic surfactants [40]. With experiments primarily involving biological dentin-substrates, the inclusion of surfactant was strictly maintained at an absolute minimum $(\sim 0.15 \%)$. 
Chlorhexidine (CHX) has been well-recognized as a bisbiguanide, dicationic surfactant and a non-specific MMPs inhibitor [14]. Interestingly, CHX incorporation correlated with a significant reduction in $z$-average diameter from $5.3 \pm 0.2 \mu \mathrm{m}$ to $1.4 \pm 0.3 \mu \mathrm{m}$ with uniform size-distribution as indicated by DLS (Table 1). The intense association between $-\mathrm{NH}_{2}$ groups in $\mathrm{CHX}$ and the hydroxyl $-\mathrm{OH}$ groups present in $\mathrm{Ca}(\mathrm{OH})_{2}$ resulted in the formation of micrometric spheres of the CHX-loaded $/ \mathrm{Ca}(\mathrm{OH})_{2}$, as verified by FTIR (Figure 4a). The initial surface retention of CHX due to competitive binding of triton X-100 [25] has attributed to surface alterations in the form of distinguishable "rounded-deposits" as identified by microscopic analyses (Figure 3b,c,f). Indication of structural changes upon entrapment was also confirmed by TGA findings (Figure 5a). Accordingly, the low $\zeta$-potential of the $\mathrm{Ca}(\mathrm{OH})_{2} /$ Blank exhibited a notable raise in the positive magnitude of the surface-charge (Table 1) suggesting successful CHX-uptake upon microparticle formation. The subsequent CHX-entrapment resulting in the uniform molecular dispersion of $\mathrm{CHX}$ in both formulations of $\mathrm{CHX}$-loaded/Ca(OH $)_{2}$ microparticles was apparent from XRD/DSC data (Figures $4 \mathrm{~b}$ and $5 \mathrm{~b}$ ). Although sufficient concentrations of the starting materials were used, with increasing $\mathrm{CHX}$ inclusion, less material would be left to bind $\mathrm{CHX}$ eventually leading to drug wastage. Moreover, the poor water solubility of $\mathrm{CHX}$ could have limited its entrapment to $\sim 62.71 \% \pm 1.2 \%$ as this procedure mainly involves water as the solvent (Table 1). As indicated in previous findings, the competitive binding of triton X-100 to CHX could have affected its incorporation in the carrier [41]. Being hydrophobic, the precipitation time of $\mathrm{CHX}$ is very short in water and to entrap it, the precipitation time of the particle carrier should be the same as the drug [42].

The defined spherical-shape, optimal $z$-average diameters $(<2 \mu \mathrm{m})$, high alkalinity, moderate drug-entrapment of the $\mathrm{CHX}$-loaded $/ \mathrm{Ca}(\mathrm{OH})_{2}$ microparticles with sustained in vitro CHX-release kinetics (Table 1 and Figures 3b,c and 9a,b) make them ideal drug delivery candidates.

The dentin-substrates prepared by wet-grinding/ultra-high polishing and ultrasonic cleaning exposed the dentin-surface for treatment [43,44]. Microparticles applied on the prepared dentin-surfaces retained an intact dense layer of evenly-distributed spherical microparticles (Figure $7 \mathrm{~b}, \mathrm{c}$ ) indicating successful delivery/attachment on the exposed dentin-surface. The unique ability of the positively-charged $\mathrm{CHX}$ - loaded $/ \mathrm{Ca}(\mathrm{OH})_{2}$ microparticles to electrostatically bind to the negative-charges in trivalent phosphate in the hydroxyapatite crystals present in dentin could be addressed as the primary reason for successful attachment of microparticles on the dentin-surface [45]. The property of the microparticles to seal the dentinal-tubules is a key feature of an ideal pulp-capping agent. The method used for dentin-substrate preparation play a significant role in the attachment/uptake of microparticles. Moreover, the quality of the dentin-surface created by different techniques might be of importance in determining the degree of microparticle interaction that remains to be explored.

Among the strategies for enhancing the uptake and even spreading of $\mathrm{CHX}$-loaded $/ \mathrm{Ca}(\mathrm{OH})_{2}$ microparticles on dentin-surfaces; the effect of micro-brush rubbing-action, the gentle air-blowing and water-blotting steps are arguably the most significant. The collective effect of these manipulative strategies might have assisted the microparticles to achieve significant degree of interaction with the dentin substrates. Additionally, further research should be done to clarify the penetration of microparticles into dentinal tubules.

The choice of distilled water has benefited as an experimental carrier/dispersion-phase for the CHX-loaded $/ \mathrm{Ca}(\mathrm{OH})_{2}$ microparticles, considering the inert/less-soluble nature of both $\mathrm{Ca}(\mathrm{OH})_{2}$ and $\mathrm{CHX}$ in water [46]. Evidence from our pilot studies (unpublished observations) suggested that the microparticles/carrier ratio of $1 / 1(w t / v)$ was the most effective in establishing a balance between sufficient microparticles retention onto dentin-surfaces and thus, not adversely affecting the functionality of microparticles following contact. In this study, dried microparticles were suspended in distilled water just prior to their application on dentin-substrates. Addressing such concerns, an immediate air-blowing and blot-drying steps were included after microparticles application, aiming to mitigate the debinding effect of water on CHX. Further research focusing on different 
types of microparticle carriers and microparticles/carrier ratios are currently under scrutiny. Moreover, the influence of microparticle storage related parameters, stability in dispersion-phase and their corresponding effect on microparticles delivery and CHX-release kinetics require further assessment.

The effects of $\mathrm{Ca}(\mathrm{OH})_{2}$ and $\mathrm{CHX}$ on the viability of the human mesenchymal stem cells (hMSCs) have been documented earlier $[47,48]$. The hMSCs population present in dental pulps are called dental pulp stem cells (DPSCs) [49]. Results of the current study showed enhanced biocompatibility of microparticles to hMSCs (after $24 \mathrm{~h}$ ), at the proposed concentrations, in comparison to that of commercial $\mathrm{Ca}(\mathrm{OH})_{2}$ powder, pure $\mathrm{CHX}$ and Dycal, thereby demonstrating the prospects of a better and successful pulp-protective material (Figure 6b). It must be noted that for cytotoxicity experiments, dried powders of microparticles suspended in culture medium was used instead of the prepared microparticle suspensions. This type of dilution could influence and therefore, result in a change in the interaction upon initial exposure to the cells. Although, microparticles were delivered in the deepest layer of dentin adjoining the pulp, limitations pertaining to the thickness of dentin, patency of tubules and the effect of simulated pulpal pressure have to be further scrutinized. The presence of at least 0.5 to $1 \mathrm{~mm}$ dentin above the pulp and dentinal-fluid has known to render a buffering role that could further mitigate the toxic effects of microparticles, if any [50]. However, the tissue responses to calcium hydroxide are not always predictable [51]. Following pulp capping, a restoration must be applied. Therefore, toxicity of the pulp-capping material in addition to that of the restoration material must be considered [52]. It is noteworthy to mention that cytotoxicity assay only reflects the initial toxicity of microparticles utilized in this study. Further examination is essential to estimate the effect of sustained CHX-release for longer culture periods.

The antibacterial activity of pulp-capping agents has been widely evaluated with the agar-diffusion test $[53,54]$. Studies have attested to the diminished efficacy of $\mathrm{CHX}$ and $\mathrm{Ca}(\mathrm{OH})_{2}$ combination in eliminating the bacterial activity [55], as supported by current findings (Table 2). The antimicrobial activity of $\mathrm{CHX}$ is achieved with a $\mathrm{pH}$ range of 5.5 to 7.0 [56]. Alkalinizing the $\mathrm{pH}$ by addition of $\mathrm{Ca}(\mathrm{OH})_{2}$ deprotonates $\mathrm{CHX}$ and alters the molecular charge resulting in decreased solubility and reduced interaction with bacterial surfaces $[57,58]$. However, our data contradicted studies emphasizing on direct contact to achieve anti-bacterial effect [59]. Dycal and commercial $\mathrm{Ca}(\mathrm{OH})_{2}$ powder showed even lower antibacterial efficacy in accordance with previous studies [60]. The inherent resistance of bacterial biofilms to antimicrobial compounds has been well chronicled [61]. Within the limitations of our study, CHX-loaded $/ \mathrm{Ca}(\mathrm{OH})_{2}$ microparticles showed more antibacterial efficiency on S. mutans (Figure 8b,c) as opposed to the recalcitrance exhibited by E. faecalis (Figure 8e,f) probably due to diffusion limitations posed by the extracellular matrix [62]. Nevertheless, these results can only be interpreted as a reference as they may not demonstrate the full clinical potential of the microparticles being tested. Future studies should be performed for longer time periods to further investigate the effect of prolonged CHX-release. An association between the release of $\mathrm{OH}^{-}$ions and anti-microbial activity of $\mathrm{Ca}(\mathrm{OH})_{2}$ has been elucidated [63]. Further studies are needed to explore its effect on antibacterial action.

From the in vitro CHX-release profiles, we observed highest cumulative $\mathrm{CHX}$-release from microparticles at the formulation of $\mathrm{CHX}: \mathrm{Ca}(\mathrm{OH})_{2} / 50 \mathrm{mg}$ at $\sim 15$ days (Figure $9 \mathrm{a}$ ). The difference in CHX-release from different microparticles could be attributed to variations in drug-loading and strength of interactions involved in CHX-binding to the $\mathrm{Ca}(\mathrm{OH})_{2}$. The presence of $\mathrm{CHX}$ retained on the surface of $\mathrm{Ca}(\mathrm{OH})_{2}$ microparticles might contribute to rapid $\mathrm{CHX}$-release (Figure 3e). The fact that $\mathrm{Ca}(\mathrm{OH})_{2}$ is slightly-soluble in water might have resulted in its escape from the dispersed phase to the aqueous release medium (PBS) with simultaneous liberation of CHX [64]. The hydrophilic affinity of polyethylene oxide head group present in triton X-100 could also have expedited the drug-release in vitro [65]. Moreover, the effect of composition of $\mathrm{CaCl}_{2}$ and $\mathrm{NaOH}$ used to form microparticles and their ionic dissociation into calcium $\left(\mathrm{Ca}^{2+}\right)$ and hydroxyl $\left(\mathrm{OH}^{-}\right)$ions on the drug-release behavior has to be further probed. 
The capacity of microparticles to remain attached to dentin-surfaces and seal the dentinal-tubules is vital for prolonged CHX-release following delivery. The ex vivo CHX-release profiles from microparticles delivered to dentin-surfaces followed the same pattern but has demonstrated lesser CHX-release than that determined in in vitro experiments (Figure 9b). Under such conditions, CHX after release from the microparticles could non-specifically bind to the mineral hydroxyapatite crystallites on the dentin-surface. The spaces between collagen-fibrils are occupied by mineral crystallites resulting in low porosity of the mineralized dentin [66]. Moreover, CHX released from microparticles occluding the dentinal-tubules could also diffuse and bind to the mineral inside the tubular wall. It is noteworthy that the surface-treated and sealed dentin-specimens were covered with filter-papers having pore-size smaller than the $z$-average diameter of the microparticles in order to prevent their escape to the surrounding PBS release medium from which CHX-release was detected. A low percentage (\%) CHX-release in the surrounding PBS medium implied substantial CHX retention on the dentin-surface following release from CHX-loaded $/ \mathrm{Ca}(\mathrm{OH})_{2}$ microparticles (Figure 9b). However, further evaluation is mandatory to directly quantify the amount of CHX retained on the dentin-surfaces.

Preservation of high alkalinity for prolonged time-periods has been regarded as one of the major advantages of $\mathrm{Ca}(\mathrm{OH})_{2}$ [67]. In the present study, $\mathrm{Ca}(\mathrm{OH})_{2}$ microparticles have been loaded with $\mathrm{CHX}$, a component more functional at a lower $\mathrm{pH}$ environment. Nevertheless, it can be observed that $\mathrm{CHX}$ incorporation has not adversely affected the alkalinity of $\mathrm{CHX}$-loaded $/ \mathrm{Ca}(\mathrm{OH})_{2}$ microparticles as the high $\mathrm{pH}$ values were maintained throughout (Figure 6a), as indicated in earlier studies [18]. When performing pulp capping, such high alkalinity of $\mathrm{Ca}(\mathrm{OH})_{2}$ is known to incite an irritation potential, capable of inducing coagulation necrosis at the contact surface of the pulp [68]. Accordingly, the high $\mathrm{pH}$ values of the $\mathrm{CHX}$-loaded $/ \mathrm{Ca}(\mathrm{OH})_{2}$ microparticles (at 15 days) indicate their promising potential for reparative dentin barrier formation. However, experiments involving a vital pulp and corresponding histological evaluation of the dentin-bridge formation will provide fertile ground for future research. Previous literature findings have reported formation of mineralized tissue from $\sim 7$ th to 10th day upon contact with $\mathrm{Ca}(\mathrm{OH})_{2}$, with complete bridge formation in 4 weeks sealing pulp exposure $[68,69]$. In the present study, in vitro $\mathrm{CHX}$-release profiles show $\sim 94.94 \%$ of $\mathrm{CHX}$ released in $\sim 15$ days (Figure $9 \mathrm{a}$ ) and it is anticipated that the $\mathrm{CHX}$-loaded $/ \mathrm{Ca}(\mathrm{OH})_{2}$ microparticles continue to release $\mathrm{CHX}$ in a sustained manner beyond this specified time-period. Until the process of dentin bridge formation is complete, we expect that the CHX-released from the microparticles remain bound to dentin-matrix and protect the exposed pulp from bacterial microleakage and MMPs mediated degradation [70]. Moreover, the antibacterial effect of $\mathrm{CHX}$-loaded $/ \mathrm{Ca}(\mathrm{OH})_{2}$ microparticles is anticipated to minimize microleakage-mediated pulpal irritation. Furthermore, it would be essential to scrutinize whether the amount of CHX released from microparticles on dentin-substrates would be adequate for the long-term antibacterial efficacy and inhibition of endogenous host-derived dentin MMPs prior to establishing the next phase of this study.

\section{Conclusions}

This study introduces novel formulations of $\mathrm{CHX}$-loaded/Ca(OH $)_{2}$ microparticles with potential dental application as a pulp-capping material. The formulated $\mathrm{CHX}$-loaded $/ \mathrm{Ca}(\mathrm{OH})_{2}$ microparticles proved good antibacterial efficacy and demonstrated the ability to release significant quantities of CHX up to 15 days while maintaining high alkalinity. The potential ability of these drug-loaded microparticles to induce reparative dentin formation, non-specific MMPs inhibition and dentin-remineralization is promising and encourages further investigation.

Acknowledgments: This work was supported by the Ministry of Education, Singapore; NUHS Oral Health Seed Grant (\# R221000078733). We greatly appreciate the technical assistance of Lucas Lu Thong Beng, C.J. Seneviratne and T.N.Q. Thuyen in the antibacterial assay.

Author Contributions: B.M.P. contributed to design, data acquisition, analysis, and interpretation, drafted the manuscript; S.T.S. and K.N., contributed to design, critically revised the manuscript; A.S.F., contributed 
to conception, data analysis, and interpretation, critically revised the manuscript; All authors agreed to be accountable for all aspects of this work.

Conflicts of Interest: The authors declare no conflict of interest.

Ethical approval \& Informed consent: Generic ethical approval and consent has been acquired for research to be conducted on the collected teeth from the Institutional Review Board of the National University of Singapore.

\section{References}

1. Ghoddusi, J.; Forghani, M.; Parisai, I. New approaches in vital pulp therapy in permanent teeth. Iran. Endod. J. 2013, 9, 15-22. [PubMed]

2. Zhang, W.; Yelick, P.C. Vital pulp therapy-Current progress of dental pulp regeneration and revascularization. Int. J. Dent. 2010, 2010, 856087. [CrossRef] [PubMed]

3. Sawicki, L.; Pameijer, C.H.; Emerich, K.; Adamowicz-Klepalska, B. Histological evaluation of mineral trioxide aggregate and calcium hydroxide in direct pulp capping of human immature permanent teeth. Am. J. Dent. 2008, 21, 262-266. [PubMed]

4. Harandi, A.; Forghani, M.; Ghoddusi, J. Vital pulp therapy with three different pulpotomy agents in immature molars: A case report. Iran. Endod. J. 2013, 8, 145-148. [PubMed]

5. Hermann, B.W. Kalziumhydroxid als Mittel zum Behandeln und Fullen von Zahnwurzelkanälen. Med. Diss. Univ. Würzburg 1920. (In German)

6. Mohammadi, Z.; Shalavi, S.; Yazdizadeh, M. Antimicrobial activity of calcium hydroxide in endodontics: A review. Chonnam. Med. J. 2012, 48, 133-140. [CrossRef] [PubMed]

7. Eidelman, E.; Finn, S.; Koulourides, T. Remineralization of carious dentin treated with calcium hydroxide. J. Dent. Child. 1964, 32, 218-225.

8. Stanley, H.; Lundy, T. Dycal therapy for pulp exposures. Oral Surg. Oral Med. Oral Pathol. 1972, 34, 818-827. [CrossRef]

9. Tronstad, L.; Mjör, I.A. Pulp reactions to calcium hydroxide-containing materials. Oral Surg. Oral Med. Oral Pathol. 1972, 33, 961-965. [CrossRef]

10. Graham, L.; Cooper, P.R.; Cassidy, N.; Nor, J.E.; Sloan, A.J.; Smith, A.J. The effect of calcium hydroxide on solubilisation of bio-active dentine matrix components. Biomaterials 2006, 27, 2865-2873. [CrossRef] [PubMed]

11. Accorinte, M.; Loguercio, A.D.; Reis, A.; Carneiro, E.; Grande, R.; Murata, S.; Holland, R. Response of human dental pulp capped with MTA and calcium hydroxide powder. Oper. Dent. 2008, 33, 488-495. [CrossRef] [PubMed]

12. Cox, C.; Sübay, R.; Ostro, E.; Suzuki, S.; Suzuki, S. Tunnel defects in dentin bridges: Their formation following direct pulp capping. Oper. Dent. 1995, 21, 4-11.

13. Pameijer, C.; Norval, G. Pulp Capping with an Experimental Hemostatic Agent and Calcium Hydroxide. J. Dent. Res. 2002, 81, A237.

14. Boushell, L.W.; Swift, J.; Edward, J. Dentin Bonding: Matrix Metalloproteinases and Chlorhexidine. J. Esthet. Restor. Dent. 2011, 23, 347-352. [CrossRef] [PubMed]

15. De Magalhaes Silveira, C.F.; Cunha, R.S.; Fontana, C.E.; de Martin, A.S.; de Almeida Gomes, B.P.F.; Motta, R.H.L.; da Silveira Bueno, C.E. Assessment of the antibacterial activity of calcium hydroxide combined with chlorhexidine paste and other intracanal medications against bacterial pathogens. Eur. J. Dent. 2011, 5, $1-7$.

16. Rathke, A.; Meisohle, D.; Bokelmann, J.; Haller, B. Antibacterial activity of calcium hydroxide and chlorhexidine containing points against Fusobacterium nucleatum and Parvimonas micra. Eur. J. Dent. 2012, 6, 434-439. [PubMed]

17. Mohammadi, Z.; Abbott, P.V. Antimicrobial substantivity of root canal irrigants and medicaments: A review. Aust. Endod. J. 2009, 35, 131-139. [CrossRef] [PubMed]

18. Haenni, S.; Schmidlin, P.; Mueller, B.; Sener, B.; Zehnder, M. Chemical and antimicrobial properties of calcium hydroxide mixed with irrigating solutions. Int. Endod. J. 2003, 36, 100-105. [CrossRef] [PubMed]

19. Almyroudi, A.; Mackenzie, D.; McHugh, S.; Saunders, W. The effectiveness of various disinfectants used as endodontic intracanal medications: An in vitro study. J. Endod. 2002, 28, 163-167. [CrossRef] [PubMed] 
20. Basrani, B.; Tjäderhane, L.; Santos, J.M.; Pascon, E.; Grad, H.; Lawrence, H.P.; Friedman, S. Efficacy of chlorhexidine-and calcium hydroxide-containing medicaments against Enterococcus faecalis in vitro. Oral Surg. Oral Med. Oral Pathol. Oral Radiol. Endod. 2003, 96, 618-624. [CrossRef]

21. Taglieri, G.; Mondelli, C.; Daniele, V.; Pusceddu, E.; Trapananti, A. Synthesis and X-ray diffraction analyses of calcium hydroxide nanoparticles in aqueous suspension. Adv. Mater. Phys. Chem. 2013, 3, 108-112. [CrossRef]

22. Carretti, E.; Chelazzi, D.; Rocchigiani, G.; Baglioni, P.; Poggi, G.; Dei, L. Interactions between nanostructured calcium hydroxide and acrylate copolymers: Implications in cultural heritage conservation. Langmuir 2013, 29, 9881-9890. [CrossRef] [PubMed]

23. Vitkov, L.; Hannig, M.; Krautgartner, W.; Herrmann, M.; Fuchs, K.; Klappacher, M.; Hermann, A. Ex vivo gingival-biofilm consortia. Lett. Appl. Microbiol. 2005, 41, 404-411. [CrossRef] [PubMed]

24. Rodriguez-Navarro, C.; Suzuki, A.; Ruiz-Agudo, E. Alcohol dispersions of calcium hydroxide nanoparticles for stone conservation. Langmuir 2013, 29, 11457-11470. [CrossRef] [PubMed]

25. Zhang, F.; Jia, Z.; Srinivasan, M. Application of direct covalent molecular assembly in the fabrication of polyimide ultrathin films. Langmuir 2005, 21, 3389-3395. [CrossRef] [PubMed]

26. Villalaín, J.; Gómez-Fernandez, J.C.; Prieto, M.J. Structural information on probe solubilization in micelles by FT-IR spectroscopy. J. Colloid Interface Sci. 1988, 124, 233-237. [CrossRef]

27. Daniele, V.; Taglieri, G. Synthesis of $\mathrm{Ca}(\mathrm{OH})_{2}$ nanoparticles with the addition of Triton X-100. Protective treatments on natural stones: Preliminary results. J. Cult. Herit. 2012, 13, 40-46. [CrossRef]

28. Kim, T.; Olek, J. Effects of sample preparation and interpretation of thermogravimetric curves on calcium hydroxide in hydrated pastes and mortars. Transp. Res. Rec. 2012, 2290, 10-18. [CrossRef]

29. Gooch, J.W.; Johnston, A.W.; Johnston, A.F. Broad Spectrum Antimicrobial Purification Materials and Methods for Purifying Fluids. US Patents US7427409 B2, 11 December 2008.

30. Stanley, H.R. Pulp capping: Conserving the dental pulp-Can it be done? Is it worth it? Oral Surg. Oral Med. Oral Pathol. 1989, 68, 628-639. [CrossRef]

31. Stanley, H. Criteria for standardizing and increasing credibility of direct pulp capping studies. Am. J. Dent. 1998, 11, S17-S34. [PubMed]

32. Qureshi, A.; Soujanya, E.; Nandakumar, P. Recent advances in pulp capping materials: An overview. J. Clin. Diagn. Res. 2014, 8, 309-316. [CrossRef] [PubMed]

33. Freire, L.G.; Carvalho, C.N.; Ferrari, P.H.P.; Siqueira, E.L.; Gavini, G. Influence of dentin on pH of $2 \%$ chlorhexidine gel and calcium hydroxide alone or in combination. Dent. Traumatol. 2010, 26, 276-280. [CrossRef] [PubMed]

34. Silva, A.; Tarquinio, S.; Demarco, F.; Piva, E.; Rivero, E. The influence of haemostatic agents on healing of healthy human dental pulp tissue capped with calcium hydroxide. Int. Endod. J. 2006, 39, 309-316. [CrossRef] [PubMed]

35. Bal, C.; Alacam, A.; Tuzuner, T.; Tirali, R.E.; Baris, E. Effects of antiseptics on pulpal healing under calcium hydroxide pulp capping: A pilot study. Eur. J. Dent. 2011, 5, 265-272. [PubMed]

36. Hörsted-Bindslev, P.; Vilkinis, V.; Sidlauskas, A. Direct capping of human pulps with a dentin bonding system or with calcium hydroxide cement. Oral Surg. Oral Med. Oral Pathol. Oral Radiol. Endod. 2003, 96, 591-600. [CrossRef]

37. Strom, T.; Arora, A.; Osborn, B.; Karim, N.; Komabayashi, T.; Liu, X. Endodontic release system for apexification with calcium hydroxide microspheres. J. Dent. Res. 2012, 91, 1055-1059. [CrossRef] [PubMed]

38. Taglieri, G.; Mondelli, C.; Daniele, V.; Pusceddu, E.; Scoccia, G. Synthesis, Textural and structural properties of calcium hydroxide nanoparticles in hydro-alcoholic suspension. Adv. Mater. Phys. Chem. 2014, 4, 50-59. [CrossRef]

39. Samanta, A.; Chanda, D.K.; Das, P.S.; Ghosh, J.; Mukhopadhyay, A.K.; Dey, A. Synthesis of Nano Calcium Hydroxide in Aqueous Medium. J. Am. Ceram. Soc. 2015, 99, 787-795. [CrossRef]

40. Doi, K.; Aki, H. Chlorhexidine Gluconate-coNtaining, Stabilized Aqueous Pharmaceutical Preparations. US Patents US5908865 A, 1 June 1999.

41. Osorio, R.; Osorio, E.; Medina-Castillo, A.L.; Toledano, M. Polymer Nanocarriers for Dentin Adhesion. J. Dent. Res. 2014, 93, 1258-1263. [CrossRef] [PubMed]

42. Balagopal, S.; Arjunkumar, R. Chlorhexidine: The gold standard antiplaque agent. J. Pharm. Sci. Res. 2013, 5, 270-274. 
43. Violich, D.; Chandler, N. The smear layer in endodontics-A review. Int. Endod. J. 2010, 43, 2-15. [CrossRef] [PubMed]

44. Kubinek, R.; Zapletalova, Z.; Vujtek, M.; Novotný, R.; Chmelickova, H. Examination of Dentin Surface Using AFM and SEM; Formatex Reserch Center: Badajoz, Spain, 2007; pp. 593-598.

45. Schuurs, A.; Gruythuysen, R.; Wesselink, P. Pulp capping with adhesive resin-based composite vs. calcium hydroxide: A review. Dent. Traumatol. 2000, 16, 240-250. [CrossRef]

46. Signoretti, F.G.C.; de Almeida Gomes, B.P.F.; Montagner, F.; Tosello, F.B.; Jacinto, R.C. Influence of $2 \%$ chlorhexidine gel on calcium hydroxide ionic dissociation and its ability of reducing endotoxin. Oral Surg. Oral Med. Oral Pathol. Oral Radiol. Endod. 2011, 111, 653-658. [CrossRef] [PubMed]

47. Trevino, E.G.; Patwardhan, A.N.; Henry, M.A.; Perry, G.; Dybdal-Hargreaves, N.; Hargreaves, K.M.; Diogenes, A. Effect of irrigants on the survival of human stem cells of the apical papilla in a platelet-rich plasma scaffold in human root tips. J. Endod. 2011, 37, 1109-1115. [CrossRef] [PubMed]

48. Ji, Y.-M.; Jeon, S.H.; Park, J.-Y.; Chung, J.-H.; Choung, Y.-H.; Choung, P.-H. Dental stem cell therapy with calcium hydroxide in dental pulp capping. Tissue Eng. Part A 2010, 16, 1823-1833. [CrossRef] [PubMed]

49. Karaöz, E.; Demircan, P.C.; Sağlam, Ö.; Aksoy, A.; Kaymaz, F.; Duruksu, G. Human dental pulp stem cells demonstrate better neural and epithelial stem cell properties than bone marrow-derived mesenchymal stem cells. Histochem. Cell Biol. 2011, 136, 455-473. [CrossRef] [PubMed]

50. Greenhill, J.D.; Pashley, D.H. The effects of desensitizing agents on the hydraulic conductance of human dentin in vitro. J. Dent. Res. 1981, 60, 686-698. [CrossRef] [PubMed]

51. Nair, P.; Duncan, H.; Pitt Ford, T.; Luder, H. Histological, ultrastructural and quantitative investigations on the response of healthy human pulps to experimental capping with mineral trioxide aggregate: A randomized controlled trial. Int. Endod. J. 2008, 41, 128-150. [PubMed]

52. Furey, A.; Hjelmhaug, J.; Lobner, D. Toxicity of Flow Line, Durafill VS, and Dycal to dental pulp cells: Effects of growth factors. J. Endod. 2010, 36, 1149-1153. [CrossRef] [PubMed]

53. Zayed, M.; Hassan, R.; Riad, M. Evaluation of the antibacterial efficacy of different bioactive lining and pulp capping agents. Tanta Dent. J. 2015, 12, 132-139. [CrossRef]

54. Poggio, C.; Beltrami, R.; Colombo, M.; Ceci, M.; Dagna, A.; Chiesa, M. In vitro antibacterial activity of different pulp capping materials. J. Clin. Exp. Dent. 2015, 7, e584-e588. [CrossRef] [PubMed]

55. Siqueira, J.F., Jr.; Lopes, H.P.; de Uzeda, M. Recontamination of coronally unsealed root canals medicated with camphorated paramonochlorophenol or calcium hydroxide pastes after saliva challenge. J. Endod. 1998, 24, 11-14. [CrossRef]

56. Athanassiadis, B.; Abbott, P.; Walsh, L.J. The use of calcium hydroxide, antibiotics and biocides as antimicrobial medicaments in endodontics. Aust. Dent. J. 2007, 52 (Suppl. 1), S64-S82. [CrossRef] [PubMed]

57. Kanisavaran, Z.M. Chlorhexidine gluconate in endodontics: An update review. Int. Dent. J. 2008, 58, $247-257$. [CrossRef] [PubMed]

58. Mohammadi, Z.; Shalavi, S. Is Chlorhexidine an Ideal Vehicle for Calcium Hydroxide? A Microbiologic Review. Iran. Endod. J. 2012, 7, 115-122. [PubMed]

59. Stevens, R.H.; Grossman, L.I. Evaluation of the antimicrobial potential of calcium hydroxide as an intracanal medicament. J. Endod. 1983, 9, 372-374. [CrossRef]

60. Koruyucu, M.; Topcuoglu, N.; Tuna, E.B.; Ozel, S.; Gencay, K.; Kulekci, G.; Seymen, F. An assessment of antibacterial activity of three pulp capping materials on Enterococcus faecalis by a direct contact test: An in vitro study. Eur. J. Dent. 2015, 9, 240-245. [CrossRef] [PubMed]

61. Davies, D. Understanding biofilm resistance to antibacterial agents. Nat. Rev. Drug Discov. 2003, 2, 114-122. [CrossRef] [PubMed]

62. Stewart, P.S. Diffusion in biofilms. J. Bacteriol. 2003, 185, 1485-1491. [CrossRef] [PubMed]

63. Eliades, G.; Palaghias, G.; Vougiouklakis, G. Effect of acidic conditioners on dentin morphology, molecular composition and collagen conformation in situ. Dent. Mater. 1997, 13, 24-33. [CrossRef]

64. Cerda-Cristerna, B.I.; Breceda-Leija, A.; Méndez-González, V.; Chavarría-Bolaños, D.; Flores-Reyes, H.; Garrocho-Rangel, A.; Komabayashi, T.; Wadajkar, A.S.; Pozos-Guillén, A.J. Sustained release of calcium hydroxide from poly (dl-lactide-co-glycolide) acid microspheres for apexification. Odontology 2015, 104, 318-323. [CrossRef] [PubMed]

65. Rangel-Yagui, C.O.; Pessoa, A., Jr.; Tavares, L.C. Micellar solubilization of drugs. J. Pharm. Pharm. Sci. 2005, 8, 147-163. [PubMed] 
66. Kim, J.; Uchiyama, T.; Carrilho, M.; Agee, K.A.; Mazzoni, A.; Breschi, L.; Carvalho, R.M.; Tjaderhane, L.; Looney, S.; Wimmer, C.; et al. Chlorhexidine binding to mineralized versus demineralized dentin powder. Dent. Mater. 2010, 26, 771-778. [CrossRef] [PubMed]

67. Prabhakar, A.; Hadakar, G.S.; Raju, O. Comparative evaluation of $\mathrm{pH}$ and antibacterial effect of various calcium hydroxide combinations on E. faecalis and its effect on root strength: An in vitro study. Contemp. Clin. Dent. 2012, 3, 42-47. [CrossRef] [PubMed]

68. Njeh, A.; Uzunoğlu, E.; Ardila-Osorio, H.; Simon, S.; Berdal, A.; Kellermann, O.; Goldberg, M. Reactionary and reparative dentin formation after pulp capping: Hydrogel vs. Dycal. Evid. Based Endod. 2016, 1, 1-9. [CrossRef]

69. Estrela, C.; Holland, R. Calcium hydroxide: Study based on scientific evidences. J. Appl. Oral Sci. 2003, 11, 269-282. [CrossRef] [PubMed]

70. Carrilho, M.R.; Carvalho, R.M.; Sousa, E.N.; Nicolau, J.; Breschi, L.; Mazzoni, A.; Tjäderhane, L.; Tay, F.R.; Agee, K.; Pashley, D.H. Substantivity of chlorhexidine to human dentin. Dent. Mater. 2010, 26, $779-785$. [CrossRef] [PubMed]

(C) 2017 by the authors. Licensee MDPI, Basel, Switzerland. This article is an open access article distributed under the terms and conditions of the Creative Commons Attribution (CC BY) license (http:/ / creativecommons.org/licenses/by/4.0/). 